\title{
Carbon isotopic composition of suspended and sinking particulate organic matter in the northern South China Sea-From production to deposition
}

\author{
Kon-Kee Liu ${ }^{\mathrm{a}, *}$, Shuh-Ji Kao ${ }^{\mathrm{b}}$, Han-Chieh $\mathrm{Hu}^{\mathrm{a}}$, Wen-Chen Chou ${ }^{\mathrm{c}}$, \\ Gwo-Wei Hung ${ }^{\mathrm{d}}$, Chun-Mao Tseng ${ }^{\mathrm{e}}$ \\ a Institute of Hydrological Sciences, National Central University, 300 Jhongda Road, Jhongli, Taoyuan 32001, Taiwan, ROC \\ ${ }^{\mathrm{b}}$ Research Center for Environmental Changes, Academia Sinica, Taiwan, ROC \\ ${ }^{\mathrm{c}}$ Institute of Marine Environmental Chemistry and Ecology, National Taiwan Ocean University, Taiwan, ROC \\ ${ }^{\mathrm{d}}$ General Education Center, National Penghu University, Taiwan, ROC \\ eInstitute of Oceanography, National Taiwan University, Taiwan, ROC
}

Accepted 12 May 2007

Available online 23 July 2007

\begin{abstract}
Between May 2004 and March 2005, samples of suspended particulate matter (SPM) were collected from the top $200 \mathrm{~m}$ on five cruises to the South-East Asia time-series study (SEATS) Station. Isotopic and elemental analyses of the organic matter in these samples gave $\delta^{13} \mathrm{C}$ values ranging from $-25.2 \%$ to $-21.3 \%$ with a decreasing trend downward, and $\mathrm{C} / \mathrm{N}$ ratios ranging from 5.5 to 11.4 with a weighted mean value of 6.74 , which is very close to the Redfield ratio, suggesting a predominantly marine origin. The temporal isotopic variation in the surface layer has been successfully simulated with the algorithm based on diffusion-controlled carbon uptake during photosynthesis. The calculation of the carbon isotopic composition of phytoplankton was based on observed values of hydrographic, isotopic and chemical variables. It is noted that variations in the biological parameters, including the specific growth rate, enzymatic isotope fractionation during carbon fixation, cell size, and cell wall permeability, within the normal ranges may have contributed significantly to the observed isotope variability. According to simulation using the same algorithm, isotopically very light particulate organic carbon (POC) could be produced in the subsurface euphotic zone due to the much reduced specific growth rate, but the contribution of the subsurface production to the sinking flux was probably not significant. Sediment traps deployed from September 2001 to May 2002 in the northern South China Sea (SCS) provided samples for isotopic and elemental analyses of the organic matter. The measurements gave $\delta^{13} \mathrm{C}$ values ranging from $-25 \%$ to $-20.8 \%$ and $\mathrm{C} / \mathrm{N}$ ratios ranging from 5.5 to 18 . The isotopic variation of organic carbon in the sediment trap samples was successfully explained by the mixing of terrigenous organics $\left(\delta^{13} \mathrm{C}=-25.5 \%\right.$ and $\left.\mathrm{C} / \mathrm{N}=22\right)$ and marine organics $\left(\delta^{13} \mathrm{C}=-22.1 \pm 1.1 \%\right.$ and $\left.\mathrm{C} / \mathrm{N}=6.63 \pm 1\right)$. The latter composition is very close to the weighted mean composition of the suspended particulate organic matter (POM) from the top $20 \mathrm{~m}$, implying the surface water as the major source of organic matter in sinking particles. Compared to previously reported results of samples collected from the seafloor in the SCS, the inferred $\delta^{13} \mathrm{C}$ values of the marine organics in the sinking flux are lower than those $\left(\delta^{13} \mathrm{C}=-22.9 \%\right.$ to $-20.1 \%$ of the POC in the nepheloid layer, which are in turn lower than those of the organics $\left(\delta^{13} \mathrm{C}=-21.5 \%\right.$ to $-18.8 \%$ ) in surficial sediments. The progressively heavier POC below the top $200 \mathrm{~m}$ is contrary to the trend of decreasing $\delta^{13} \mathrm{C}_{\mathrm{POC}}$ in the top $200 \mathrm{~m}$. We have demonstrated that the Suess
\end{abstract}

*Corresponding author. Tel.: + 88634223354 ; fax: + 88634222894.

E-mail address: kkliu@ncu.edu.tw (K.-K. Liu). 
effect and the elevated concentration of aqueous $\mathrm{CO}_{2}$ in the surface water due to the increasing atmospheric $\mathrm{CO}_{2}$ partial pressure may cause depletion of ${ }^{13} \mathrm{C}$ more than enough to account for the observed depression of $\delta^{13} \mathrm{C}$ values in the progressively younger POM. In the past, diagentic isotopic alteration has been proposed as the process responsible for both the decreasing trend of $\delta^{13} \mathrm{C}_{\mathrm{POC}}$ in the surface layer and the increasing trend in the subsurface layer. Although the diagenetic effect cannot be ruled out, this study shows that other processes are sufficient to explain the observed trends of isotopic variation of POC.

(C) 2007 Elsevier Ltd. All rights reserved.

Keywords: Isotope fractionation; Phytoplankton growth; SEATS; Suess effect; Sediment traps; Sediments

\section{Introduction}

The South China Sea (SCS) is the largest marginal sea in the world aside from the ice-covered Arctic Ocean (Sverdrup et al., 1942). It has a deep basin reaching a maximum depth of $5006 \mathrm{~m}$ off southwest Luzon (NGDC, 2001) and is connected to the open ocean mainly through the Luzon Strait for effective water exchange with the western North Pacific. The circulation and, consequently, the biogeochemistry of the SCS are subject to forcing of the alternating East Asian monsoons (Shaw and Chao, 1994; Liu et al., 2002). Inter-annual variations in the SCS are mostly associated with modulation of the monsoon strength by El NiñoSouthern Oscillation events (Chao et al., 1996; Wu et al., 1999). On a longer time scale, variations in sedimentary records, such as organic carbon contents, during glacial-interglacial cycles were attributed to climate changes manifested as variations in monsoon strengths. The responsiveness of the SCS to climate changes has inspired active sampling of the SCS sediments (Chen et al., 1998; Prell et al., 1999). Subsequently, paleoceanographic studies on the SCS have flourished in recent years (e.g., Wang et al., 2004).

Considerable attention has been given to the isotopic records of sedimentary organic matter in the SCS (Kienast et al., 2001; Higginson et al., 2003). Because the isotopic composition of sedimentary organic matter has been widely used to estimate the $\mathrm{CO}_{2}$ partial pressure in the geological history (Rau et al., 1989), a critical evaluation was performed on the usefulness of carbon isotopic records of sedimentary organic matter from the SCS and other low-latitude oceanic sites as a proxy indicator of aqueous $\mathrm{CO}_{2}$ concentration (Kienast et al., 2001), which is related to the $\mathrm{CO}_{2}$ partial pressure in the atmosphere. The authors concluded that better constraints must be imposed on the mechanisms governing the isotopic composition of marine particulate organic carbon (POC). Therefore, it is critical to better understand the processes controlling the isotopic variation from the production to the deposition of POC in the ocean. For the SCS, there has been one study on the isotopic composition of dissolved inorganic carbon (DIC) (Lin et al., 1999), which was based on field observations conducted in 1995 and none on that of organic carbon in the SCS proper. In fact, there have been few, if any, studies, in which the isotopic compositions of POC in the entire vertical profile from the surface ocean to the nepheloid layer and the surficial sediment were examined; let alone a detailed mechanistic understanding of the processes responsible for the isotopic composition of deposited organic carbon on seafloor.

The South-East Asian Time-series study (SEATS) project (Karl et al., 2003; Tseng et al., 2005) has allowed us to conduct seasonal samplings of suspended particular organic matter (POM) at the SEATS Station $\left(18.0^{\circ} \mathrm{N}, 115.6^{\circ} \mathrm{E}\right)$ (Fig. 1A). Sediment traps deployed in the northern SCS provided samples of sinking particles for comparison (Fig. 1A). The sampling of the suspended POM covered all four seasons of an annual cycle, while the trap deployments covered three seasons. These samples together with previously reported $\delta^{13} \mathrm{C}$ data (Kienast et al., 2001) of organic matter from the fluff samples in the nepheloid layer and surficial sediments (Fig. 1B) provide us a unique opportunity to examine $\delta^{13} \mathrm{C}_{\mathrm{POC}}$ from the entire water column. Although many localities of observations discussed in this study are not close to the SEATS Station, all sites are within the oligotrophic regime of the subtropical SCS with average sea-surface chlorophyll concentration within $0.1-0.3 \mathrm{mg} \mathrm{m}^{-3}$ (Fig. 1B). It is reasonable to presume that their biogeochemical characteristics are similar, following the widely accepted principles of using ocean color data for oceanic ecological characterization (e.g., Longhurst et al., 1995; Ducklow, 2003). 
(A)

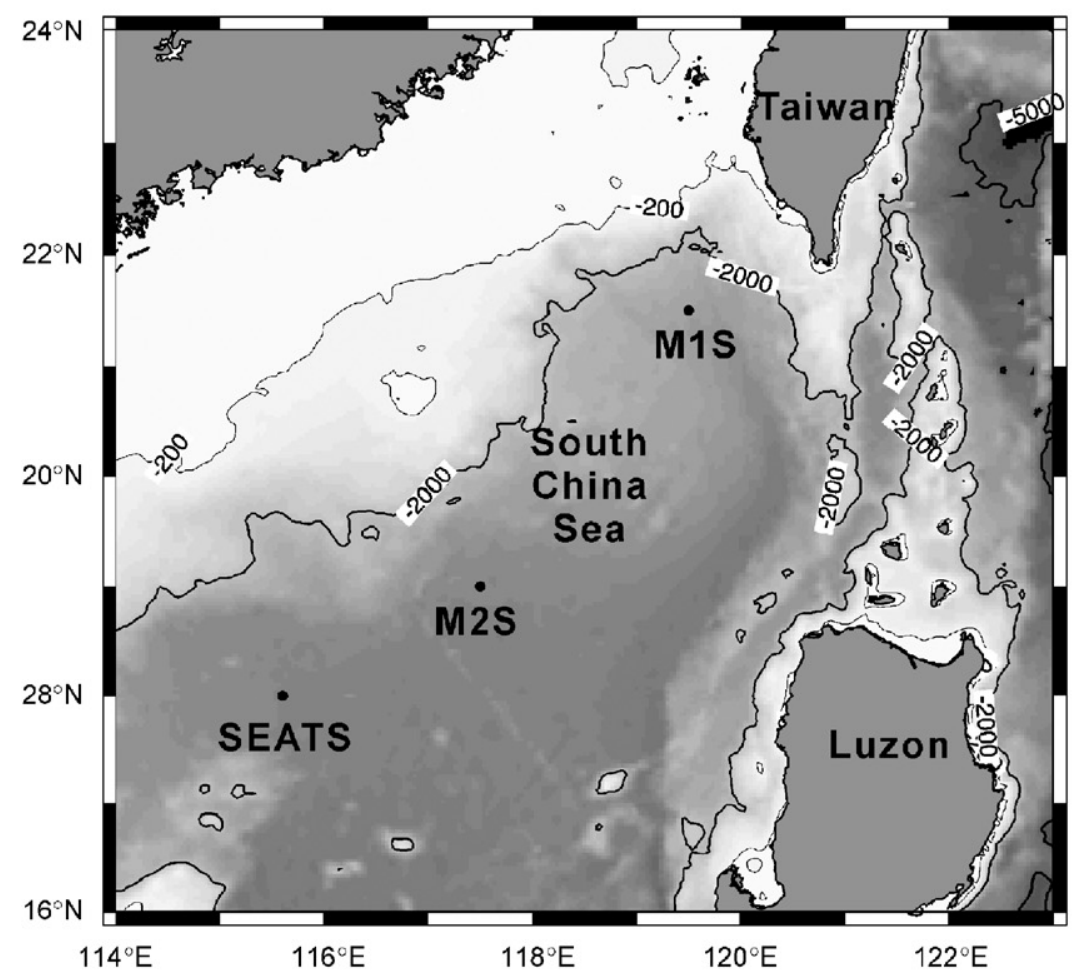

(B)

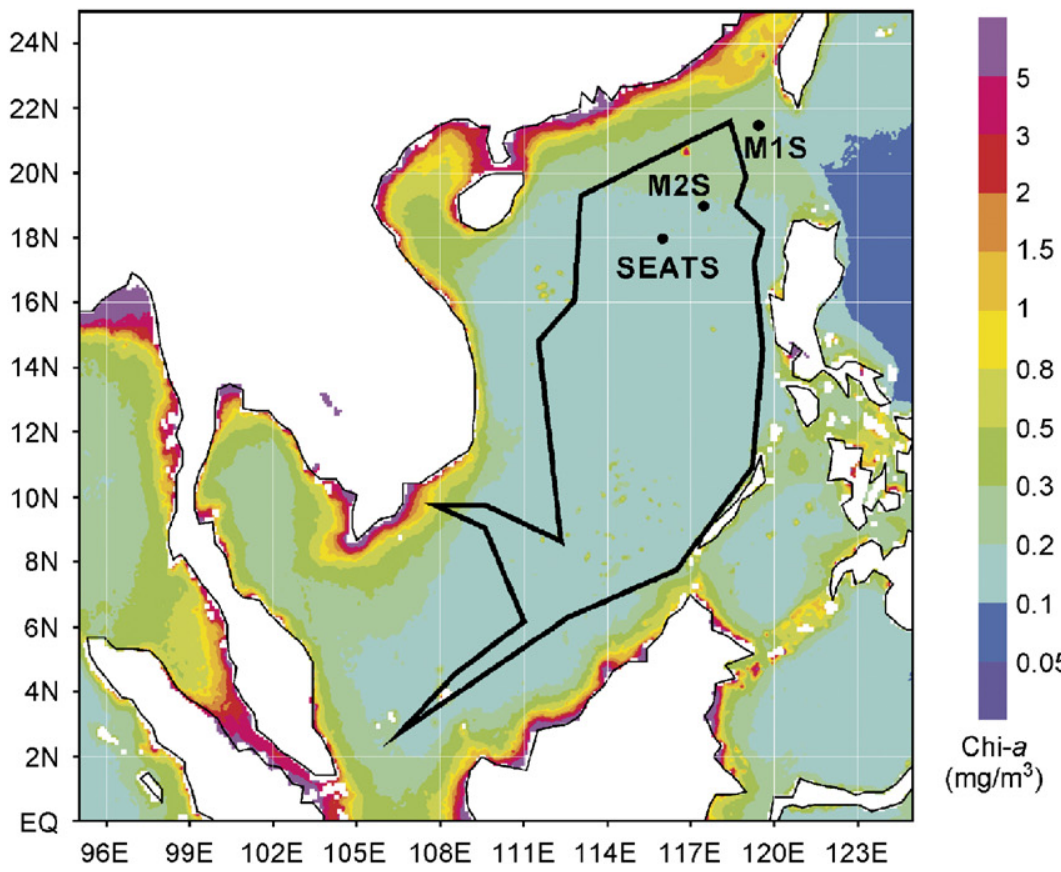

Fig. 1. Locations of sampling sites in the northern South China Sea. SEATS indicates the main site of the SEATS Station. M1S and M2S indicate sites of sediment trap deployments (Table 2). (A) Bathymetry map. (B) Average Chl- $a$ distribution derived from SeaWiFS data. The polygon indicates the sampling area of surficial sediments and the fluff materials (Kienast, 2000; Kienast et al., 2001). See text for detail. 
It is noted that other subprojects of SEATS provided ancillary data of hydrography and carbonate chemistry, which enabled us to simulate the $\delta^{13} \mathrm{C}$ values of POC produced by phytoplankton during the study period. The simulation in turn permitted us to understand better the isotopic variation of phytoplankton in the euphotic zone and to delineate relationships between the POM produced in the upper water column and the organic matter in particles sinking through the water column, resuspended in the nepheloid layer and accumulated in surficial sediments. The purpose of this study is to improve our knowledge on the factors controlling the $\delta^{13} \mathrm{C}$ value of organic matter deposited on the seafloor.

\section{Materials and methods}

\subsection{Sampling}

Water samples were collected for sampling of suspended particulate matter (SPM) on five cruises between May 2004 and March 2005 at the SEATS Station (Table 1). The CTD-Rosette sampler fitted with 20-L go-flo bottles were used for the sampling on cruises on board R/V Ocean Researcher I. Tenliter go-flo bottles were used on the FR1-SC33 cruise. Twelve to 22 samples were collected on 1-3 hydrocasts depending on the schedule of the cruise.

For collection of SPM samples, about $10 \mathrm{~L}$ of seawater were first stored by filling a opaque plastic bottle and then filtered through a Whatman quartz filter, $25 \mathrm{~mm}$ in diameter with mean pore size of $2.2 \mu \mathrm{m}$, on board the research vessel shortly after collection. Each of the opaque plastic storage bottles was calibrated for its volume before use. The quartz filters were preheated at $500{ }^{\circ} \mathrm{C}$ in an oven for the removal of organic matter and wrapped in aluminum foil before use. After filtration, the filters were folded and wrapped again in aluminum foil and stored in a freezer at $-20{ }^{\circ} \mathrm{C}$ until analysis.
The French-made time-series sediment traps, Technicap PPS $3 / 3$, were used in this study to collect settling particulate samples. This type of trap has an aspect ratio of 2.5 and a collection area of $0.125 \mathrm{~m}^{2}$. The traps were deployed at three to four depths at two sites (Table 2) near the SEATS Station in the northern SCS (Fig. 1A). Each of the two sites was occupied individually during one period between September 2001 and May 2002 (Table 2). Each collection cup was filled with a buffered $(5 \%$ or $\sim 1.7 \mathrm{M})$ formalin solution $(7.5<\mathrm{pH}<8.0)$ to poison "swimmers" and prevent the trapped particles from degradation. Nine to 12 samples were obtained from each trap for this study. Collectively they covered roughly an annual cycle.

Upon recovery of the traps, the samples were immediately stored in a cold-room below $4{ }^{\circ} \mathrm{C}$ until they were brought back to the laboratory. After removal of the supernatant, the trapped particles were wet-sieved through $1 \mathrm{~mm}$ nylon mesh with $0.2-\mu \mathrm{m}$ filtered seawater to remove large organisms. Zooplankton swimmers that passed through the sieve were manually removed under a microscope. The sample was then divided into sub-samples by a perimatic dispenser (Jencons Ltd.). One of the sub samples was filtered with a pre-weighed $47-\mathrm{mm}$ Millipore filter $(0.45-\mu \mathrm{m}$ pore size $)$ and the filtered sample was rinsed with deionized distilled water to remove the sea salt. The desalted sample was dried at $40{ }^{\circ} \mathrm{C}$ for $48 \mathrm{~h}$. Then the sample was scraped off from the filter paper, ground to powder and stored in an auto-desiccator until it was analyzed.

\subsection{Isotopic and chemical analyses}

The filters bearing SPM were dried at $70{ }^{\circ} \mathrm{C}$ in an oven, and then acidified for the removal of carbonate. The acidification was carried out by wetting the filter with $1 \mathrm{~mL}$ of $1 \mathrm{~N}$ solution of reagent grade $\mathrm{HCl}$. Afterwards the filters were dried at $60{ }^{\circ} \mathrm{C}$ in an oven for $48 \mathrm{~h}$. Dried sediment trap samples were weighed into plastic centrifuge tubes

Table 1

Sampling cruises for the collection of suspended particulate matter for carbon and nitrogen isotope analysis

\begin{tabular}{lllll}
\hline Cruise & Date & No. of hydrocasts & Depth range (m) & No. of samples \\
\hline OR1-717 & May 3-8, 2004 & 1 & $0 \sim 200$ & 10 \\
OR1-726 & August 2-6, 2004 & 1 & $0 \sim 200$ & 12 \\
OR1-736 & November 5-11, 2004 & 2 & $0 \sim 200$ & 22 \\
OR1-743 & January 20-24, 2005 & 3 & $0 \sim 300$ & 20 \\
FR1-SC33 & March 26-April 2, 2005 & 2 & $0 \sim 200$ & 22 \\
\hline
\end{tabular}


Table 2

Durations and locations of sediment traps deployed in the northern South China Sea and number of samples obtained for this study

\begin{tabular}{lllll}
\hline Site & Duration & Location & Interval & Trap depths (m) [no. of samples] \\
\hline M1S & Sept. 22, 2001-Mar. 21, 2002 & $21^{\circ} 30.9^{\prime} \mathrm{N}, 119^{\circ} 27.8^{\prime} \mathrm{E}$ & 15 days & $374[11], 925[11], 1925[12], 2700[12]$ \\
M2S & Dec. 16, 2001-May 14, 2002 & $19^{\circ} 00.0^{\prime} \mathrm{N}, 117^{\circ} 29.5^{\prime} \mathrm{E}$ & 15 days & $447[9], 1248[10], 3250[10]$ \\
\hline
\end{tabular}

and treated with $2 \mathrm{~mL}$ of $1 \mathrm{~N} \mathrm{HCl}$ solution for the removal of carbonates. The centrifuge tube bearing the sample and acid solution was dried in an oven at $50{ }^{\circ} \mathrm{C}$ for $48 \mathrm{~h}$. Then the acidification procedure was repeated once more to ensure complete removal of carbonates.

The decarbonated samples were analyzed for carbon isotopic composition and carbon/nitrogen contents in a continuous flow elemental analyzerisotope ratio mass spectrometer system. The filter and trap samples were combusted in an elemental analyzer (Flash EA-1100 NC, Thermo-Finnigan) to produce $\mathrm{CO}_{2}$ and $\mathrm{N}_{2}$, which flowed through a GC column for separation, then into a mass spectrometer (Thermo Finnigan Deltaplus Advantage) for measurements of carbon and nitrogen contents and the carbon isotopic composition. The isotopic composition is expressed in the $\delta$-notation defined as follows:

$\delta^{13} \mathrm{C}=\left(1-R_{\mathrm{sam}} / R_{\mathrm{ref}}\right) 1000 \%$,

where $R_{\text {sam }}$ is the ${ }^{13} \mathrm{C} /{ }^{12} \mathrm{C}$ ratio of the samples and $R_{\text {ref }}$ is the ratio of the reference, which is Pee Dee Belemnite (Hoefs, 1997). USGS 40 (L-glutamatic acid) and IAEA-CH6 with certified value of $-26.3 \%$ and $-10.4 \%$, respectively, were used as working standards. The long-term reproducibility of carbon isotope determination for the two international standards and field samples is better than $\pm 0.2 \%$.

Measurements of DIC and titration alkalinity (TA) for seawater samples followed the standard operating procedures (DOE, 1994). The coulometric method was used for DIC measurements with a precision of $\pm 0.1 \%$. TA was determined by the potentiometric titration method in an open cell with a precision of $\pm 0.2 \%$. Seawater references provided by A.G. Dickson of the Scripps Institution of Oceanography had been used for calibration and accuracy assessments throughout this study. Differences between the certified values and our measurements are less than 2 and $3 \mu \mathrm{mol} \mathrm{kg}^{-1}$ for DIC and $\mathrm{TA}$, respectively. The concentration of aqueous
$\mathrm{CO}_{2}$ was computed from DIC and TA data using the standard procedure (Lewis and Wallace, 1998).

For the analysis of $\delta^{13} \mathrm{C}$ of DIC, $40 \mathrm{~mL}$ of seawater were acidified with $2 \mathrm{~mL} 85 \%$ phosphoric acid in a pre-evacuated vessel, and the liberated $\mathrm{CO}_{2}$ gas was then trapped with liquid nitrogen under vacuum. Isotopic analysis was performed with a VG Optima mass spectrometer. The overall procedural error for $\delta^{13} \mathrm{C}_{\text {DIC }}$ analyses was better than $\pm 0.05 \%$.

\section{Results}

We first present isotopic compositions of POC collected from the five cruises and ancillary data obtained concurrently. Then we describe results of isotopic and elemental analyses of sediment trap samples retrieved from the two mooring sites in the northern SCS near the SEATS Station.

\subsection{Isotopic compositions of suspended particulate carbon}

The five cruises between May 2004 and March 2005 that provided samples for this study covered roughly an annual cycle. The temperature of seawater in the surface layer of $10-50 \mathrm{~m}$ (Fig. 2A) faithfully reflected the seasonal variation of hydrographic conditions as reported before (Tseng et al., 2005). The uniform temperature distribution in the top $50 \mathrm{~m}$ observed in November 2004 and January 2005 was a result of the deepest mixed layer, reaching $100 \mathrm{~m}$, in late autumn and early winter. The concentration of POC (Fig. 2B) varied in a nearly reverse relationship with the temperature change. This is consistent with the reverse relationship found between sea surface temperature and chlorophyll (Tseng et al., 2005). By contrast, the $\delta^{13} \mathrm{C}$ value of POC showed some variation (Fig. 2C), but there was no clear correlation with either of the other two parameters.

The hydrographic, chemical and isotopic profiles showed some consistent patterns of vertical variation as demonstrated by two sets of data from the 


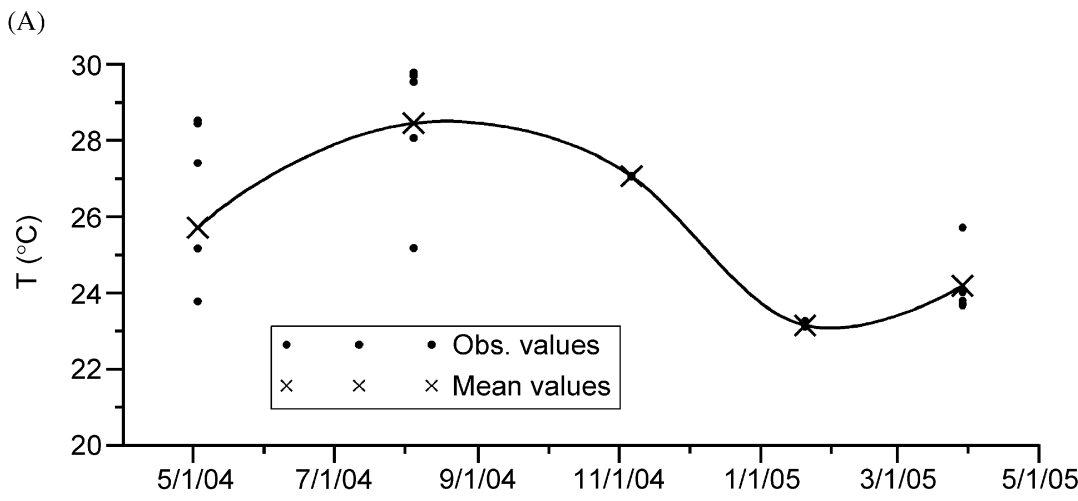

(B)

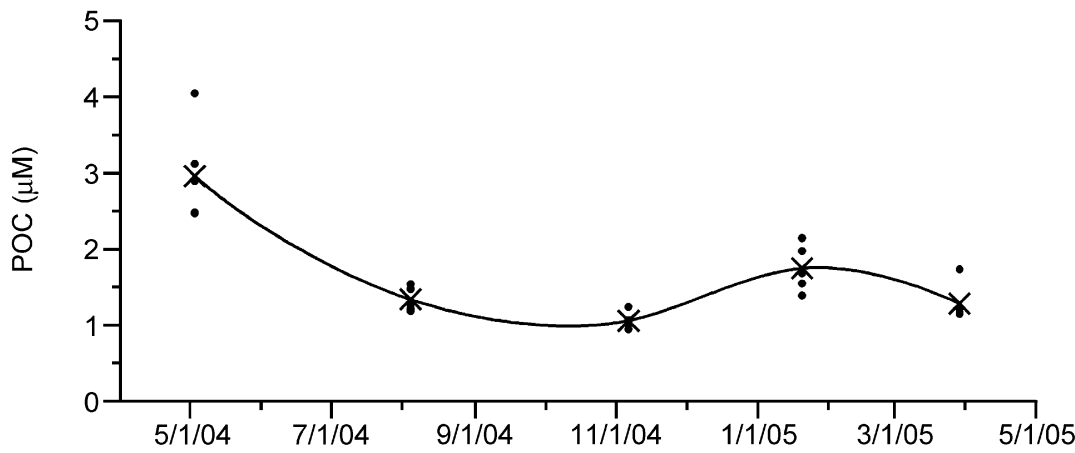

(C)

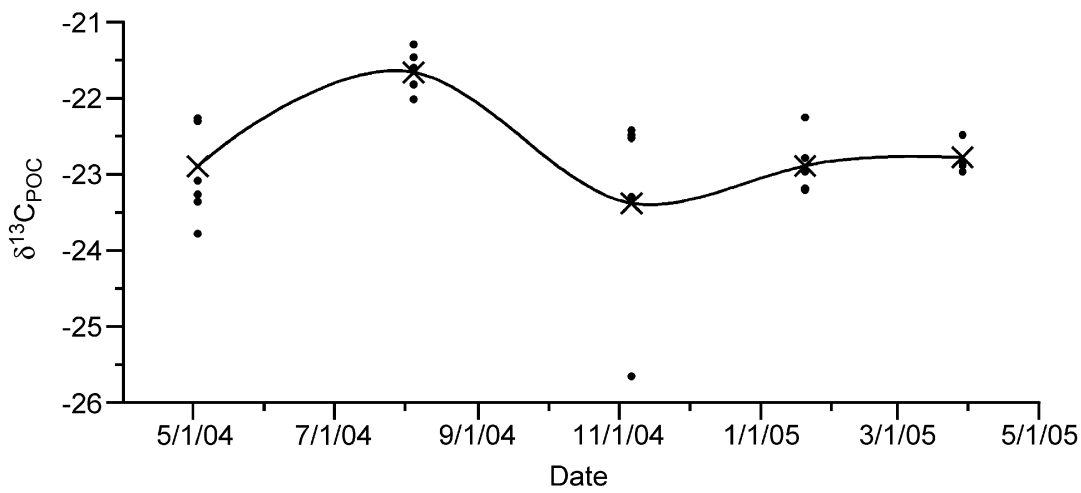

Fig. 2. Time-series of temperature and the concentration and the $\delta^{13} \mathrm{C}$ value of POC in the upper $50 \mathrm{~m}$ at the SEATS Station observed on the five cruises of this study. The samples were taken every $10 \mathrm{~m}$ starting at $10 \mathrm{~m}$ below surface. The crosses mark the mean values. The mean $\delta^{13} \mathrm{C}$ values are the concentration-weighted averages.

top $200 \mathrm{~m}$ at the SEATS Station, one from summer (Fig. 3) and the other from winter (Fig. 4). The summer condition showed a rather thin mixed layer of about $35 \mathrm{~m}$ (Fig. 3A). The $\delta^{13} \mathrm{C}$ values of POC in the mixed layer were quite uniform, while the concentration of POC showed a surface maximum (Fig. 3B). Also plotted are the concentrations of aqueous $\mathrm{CO}_{2}$ and the $\delta^{13} \mathrm{C}$ values of DIC observed on the same cruise (Fig. 3C). Both parameters were quite uniform in the mixed layer. Below the mixed layer, the concentration of POC decreased, while the DIC concentration increased. The $\delta^{13} \mathrm{C}$ values of both POC and DIC decreased, but the ranges of variation were quite different. The isotopic composition of POC varied in the range from $-24.2 \%$ to $-21.5 \%$, while that of DIC varied in a very narrow range from $0.1 \%$ to $0.9 \%$.

The winter condition showed a much thicker mixed layer, approaching $100 \mathrm{~m}$ (Fig. 4A). All carbon parameters showed rather uniform values 
(A)

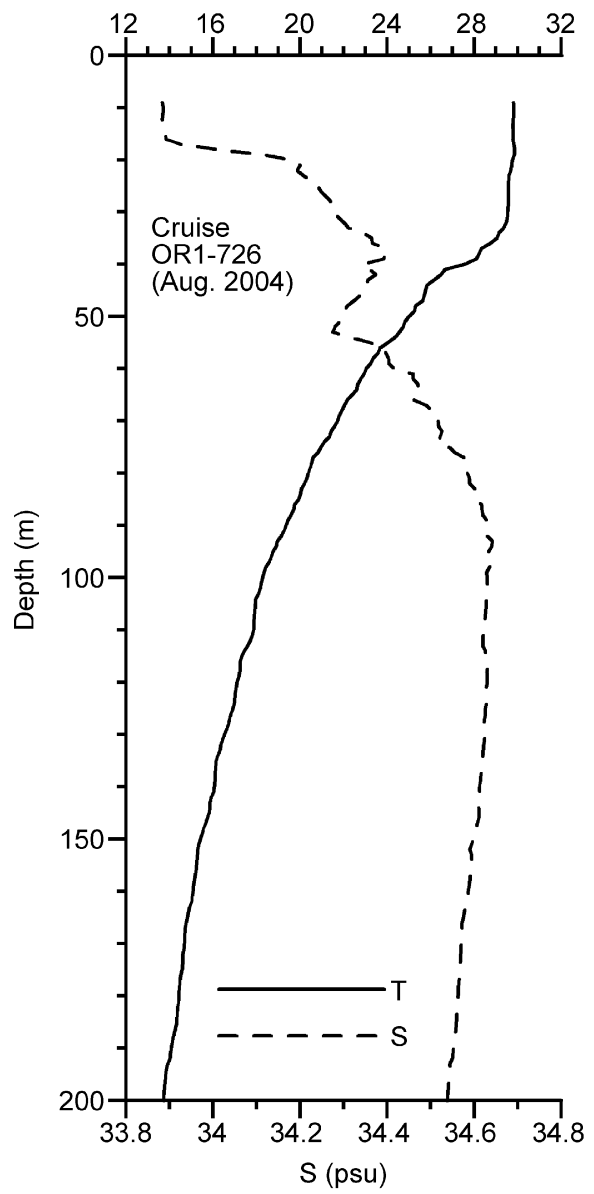

(B)

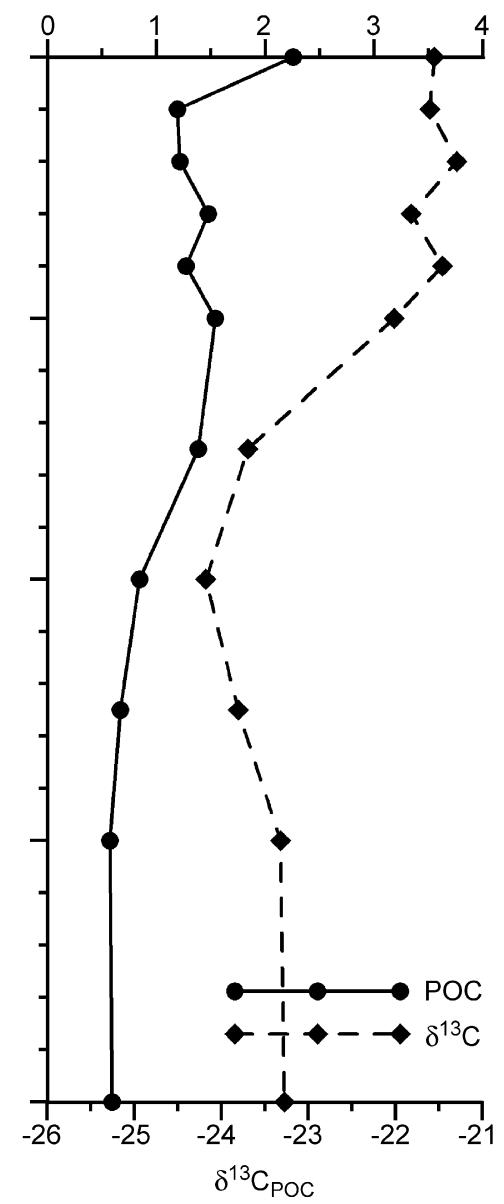

(C)

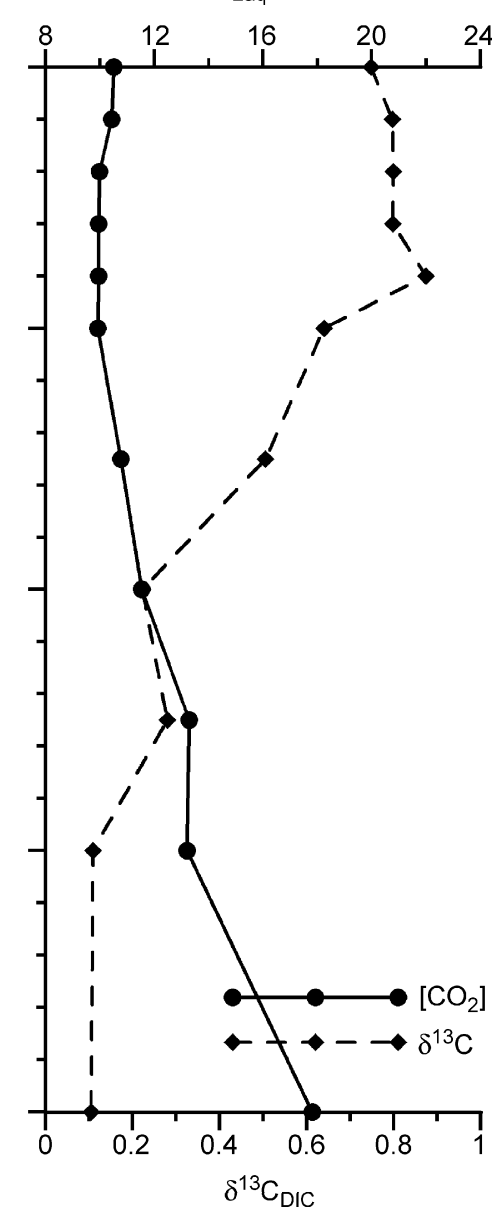

Fig. 3. Hydrography and selected carbon chemistry profiles observed at the SEATS Station on Cruise OR1-726 in August 2004 (A) Temperature and salinity profiles. (B) Profiles of POC concentration and its $\delta^{13} \mathrm{C}$ value. (C) Profiles of aqueous $\mathrm{CO}_{2}$ and the $\delta^{13} \mathrm{C}$ value of dissolved inorganic carbon.

in the mixed layer except a surface maximum of POC concentration (Fig. 4B, C). Below the mixed layer, the trends were similar to those found in summer. It is noted that the isotopic composition of POC in winter showed a narrower range from $-23.2 \%$ to $-22.3 \%$, while that of DIC showed a slightly narrower range from $0.1 \%$ to $0.8 \%$. The decreasing trend of the $\delta^{13} \mathrm{C}_{\text {DIC }}$ value with depth is consistent with previous observations in the SCS (Lin et al., 1999), but the range $(0.1-0.9 \%$ ) of all observed values in the top $200 \mathrm{~m}$ differs from the previous one $(0.5-1.6 \%)$ with the current values lower by about $0.5 \%$ on average. The shift could be attributed to the 10 years' difference between the two observations due to the Suess effect, i.e., the intrusion of the isotopically light $\mathrm{CO}_{2}$ from fossil fuel burning into the ocean (Quay et al., 2003). However, a systematic difference in the isotopic measurements cannot be ruled out, since certified reference materials for quality control of $\delta^{13} \mathrm{C}_{\mathrm{DIC}}$ measurements are not yet available. It is noted that an inter-laboratory calibration of $\delta^{13} \mathrm{C}_{\mathrm{DIC}}$ measurements was conducted during the course of this study. No systematic error was found between the values obtained in the laboratory supporting this study and the one at University of California, Davis (Chou, 2004).

The vertical trends of POC variation on all five cruises are summarized in Fig. 5. The concentration of POC decreased with depth with mean concentrations of $2.3 \mu \mathrm{M}$ for the top $20 \mathrm{~m}, 1.5 \mu \mathrm{M}$ for $21-100 \mathrm{~m}$ and $0.8 \mu \mathrm{M}$ for $101-200 \mathrm{~m}$. The $\delta^{13} \mathrm{C}$ value of POC also decreased with depth with concentration weighted mean values of $-22.1 \%$ for the top $20 \mathrm{~m},-23.0 \%$ for $21-100 \mathrm{~m}$ and $-24.0 \%$ o for $100-200 \mathrm{~m}$. 
(A)

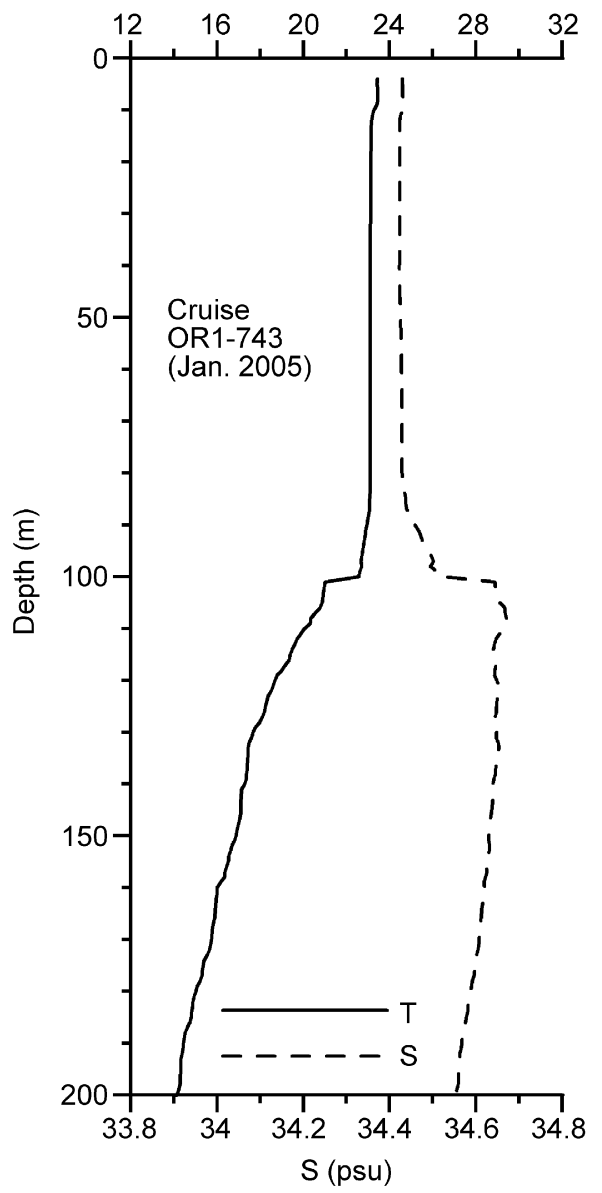

(B)

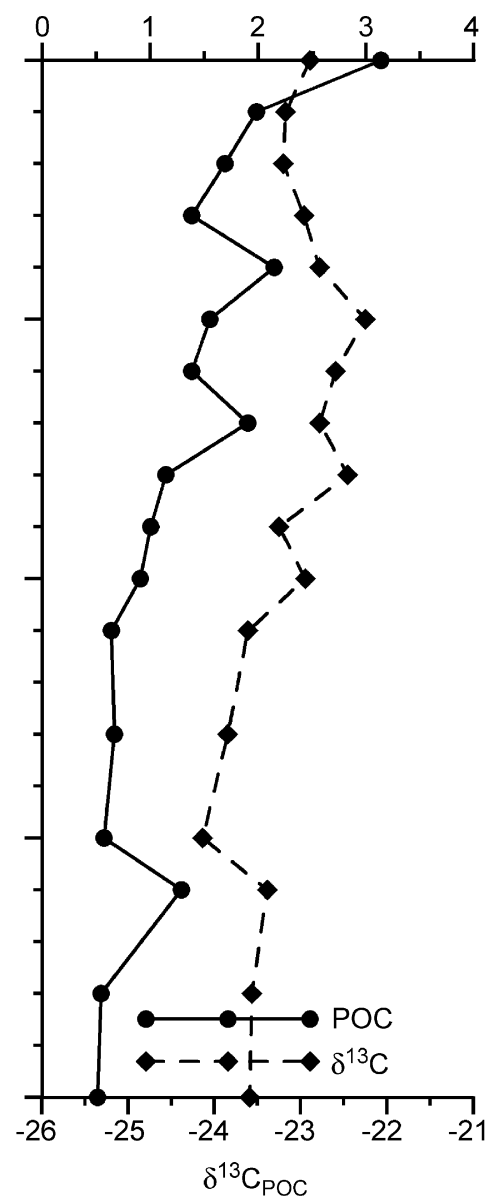

(C)

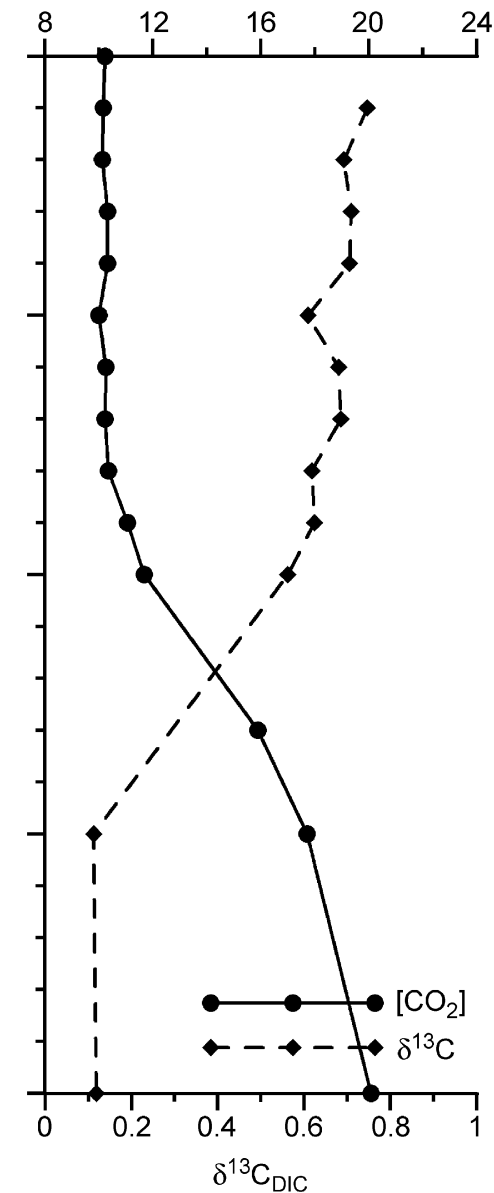

Fig. 4. The same as Fig. 2 except for OR1-743 in January 2005.

\subsection{Organic carbon isotopic compositions of sinking particles}

The organic carbon isotopic compositions of sinking particles collected in the sediment traps deployed at four depths at Site M1S are plotted in Fig. 6 and those for Site M2S are plotted in Fig. 7. Also plotted are the corresponding organic carbon contents and the $\mathrm{C} / \mathrm{N}$ ratio by atom in the same samples.

The sediment trap mooring at Site M1S was deployed from September 22, 2001 to March 20, 2002 (Table 2). The $\delta^{13} \mathrm{C}$ value varied in the range from $-23.2 \%$ to $-21.0 \%$ (Fig. 6). There was no consistent trend in the temporal variations recorded by the four traps. In terms of vertical variation, top two traps recorded a stronger variability, while the bottom two traps showed more uniform values. The organic carbon contents of the sediment trap samples decreased consistently with depth (Fig. 6) from $10 \%$ to $22 \%$ at $374 \mathrm{~m}$ to $2-3 \%$ at $2700 \mathrm{~m}$. There appeared to be a weak temporal trend of a minimum occurring in winter. The $\mathrm{C} / \mathrm{N}$ ratio varied in the range from 5.5 to 10.7 with most variability occurring in the top two traps; the bottom two traps showed quite uniform values from 7.7 to 9.4.

The sediment trap mooring at Site M2S was deployed from December 16, 2001 to May 14, 2002 (Table 2). Compared to samples from Site M1S, those from M2S had $\delta^{13} \mathrm{C}$ values varying in a wider range from $-25.0 \%$ to $-21.5 \%$ (Fig. 7). Similarly most of the variability occurred in samples from the shallowest trap at $447 \mathrm{~m}$. There was no consistent trend in the temporal variations recorded by the three traps. The organic carbon contents of the sediment trap samples also decreased consistently with depth (Fig. 6) from $29-48 \%$ at $447 \mathrm{~m}$ to $4-6 \%$ at $3250 \mathrm{~m}$. Although the shallowest trap at M2S was 

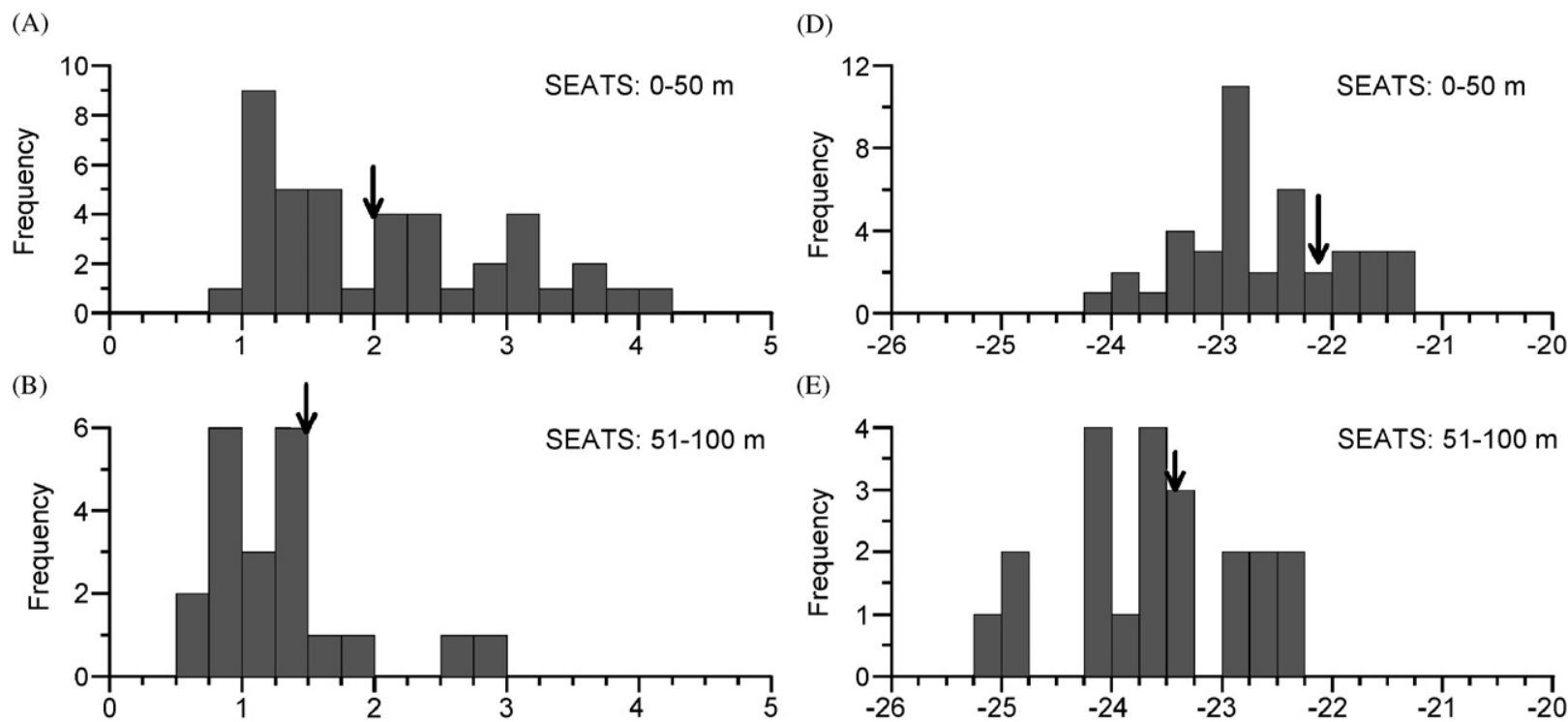

(E)
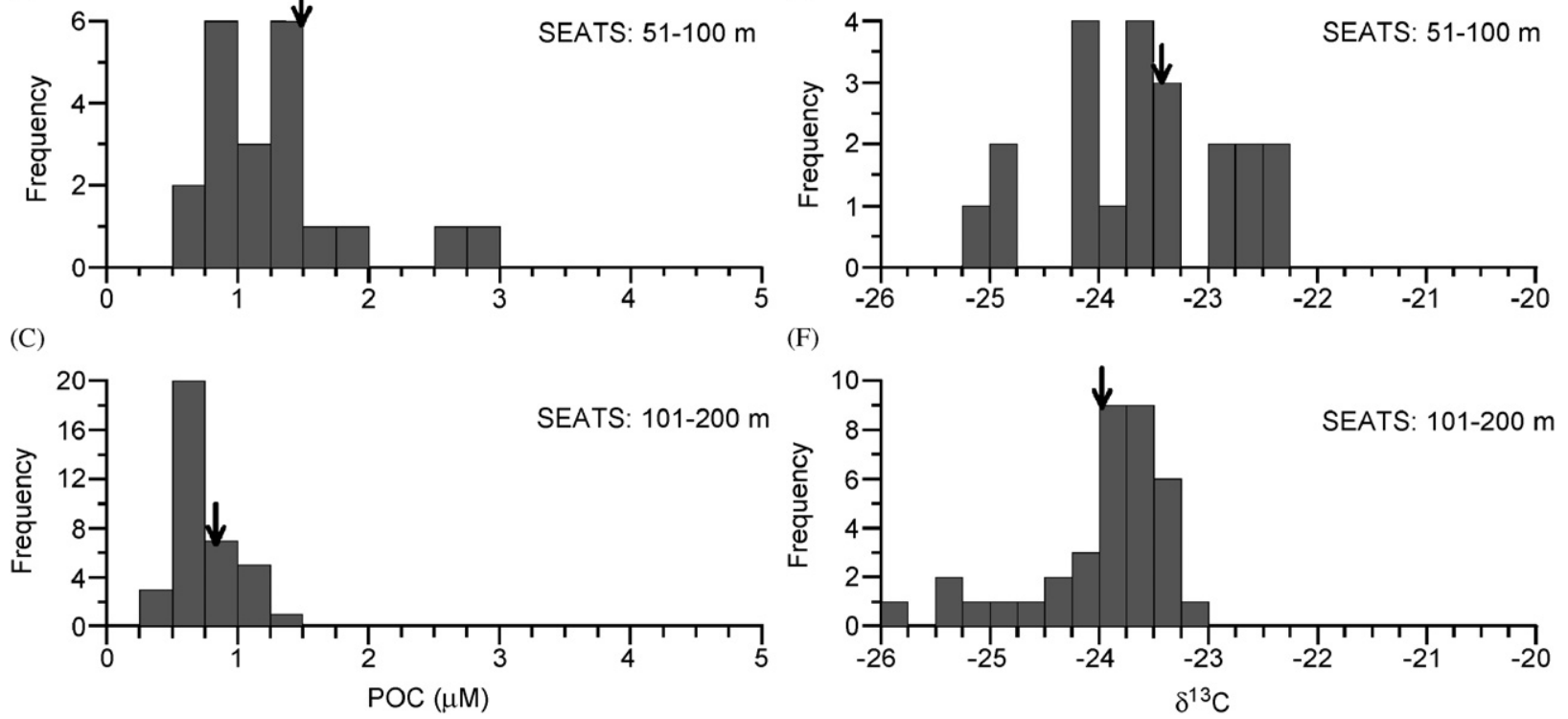

Fig. 5. Histogram of occurrences of concentrations and the $\delta^{13} \mathrm{C}$ values of POC in the upper 50, 51-100 and $101-200 \mathrm{~m}$ observed at the SEATS Station on the five cruises. The arrows indicate the mean values of concentration and the concentration weighted mean $\delta^{13} \mathrm{C}$ values of POC.

deeper than that at M1S, its trapped samples had considerably higher organic carbon contents. The range of $\mathrm{C} / \mathrm{N}$ ratios recorded in the shallowest trap was also wider with a lower bound of 5.9, similar to that recorded at M1S, but a higher upper bound of 18, which corresponded to a rather low $\delta^{13} \mathrm{C}$ value of $-24.9 \%$ (Fig. 7), suggesting a predominantly terrestrial origin. The bottom two traps showed lesser variability in the $\mathrm{C} / \mathrm{N}$ ratio with time.

\section{Discussion}

\subsection{Origin of $P O M$}

The origin of POM may be indicated by the $\mathrm{C} / \mathrm{N}$ ratio and the carbon isotopic composition (Jeffrey et al., 1983; Hayes, 1993; Middelburg and Nieuwenhuize, 1998). The concentrations of POC and particulate nitrogen as SPM collected at the SEATS Station are highly correlated (Fig. 8). The equation of linear regression is as follows:

$\mathrm{POC}=(6.36 \pm 0.16) \times \mathrm{PN}+0.09 \pm 0.04, \quad R^{2}=0.94$.

The slope of the regression line is quite close to the Redfield $\mathrm{C} / \mathrm{N}$ ratio of 6.63 , suggesting that most of the variation of POM in the upper water column was attributable to marine organic matter.

In contrast to the very coherent relationship between POC and PN, the relationship between organic carbon and nitrogen contents in sinking particles collected by sediment traps is more scattered (Fig. 9). Even so, the data points are scattered about the line of Redfield ratio with obvious deviation towards the higher $\mathrm{C} / \mathrm{N}$ ratio, indicating contribution of terrigenous materials. 

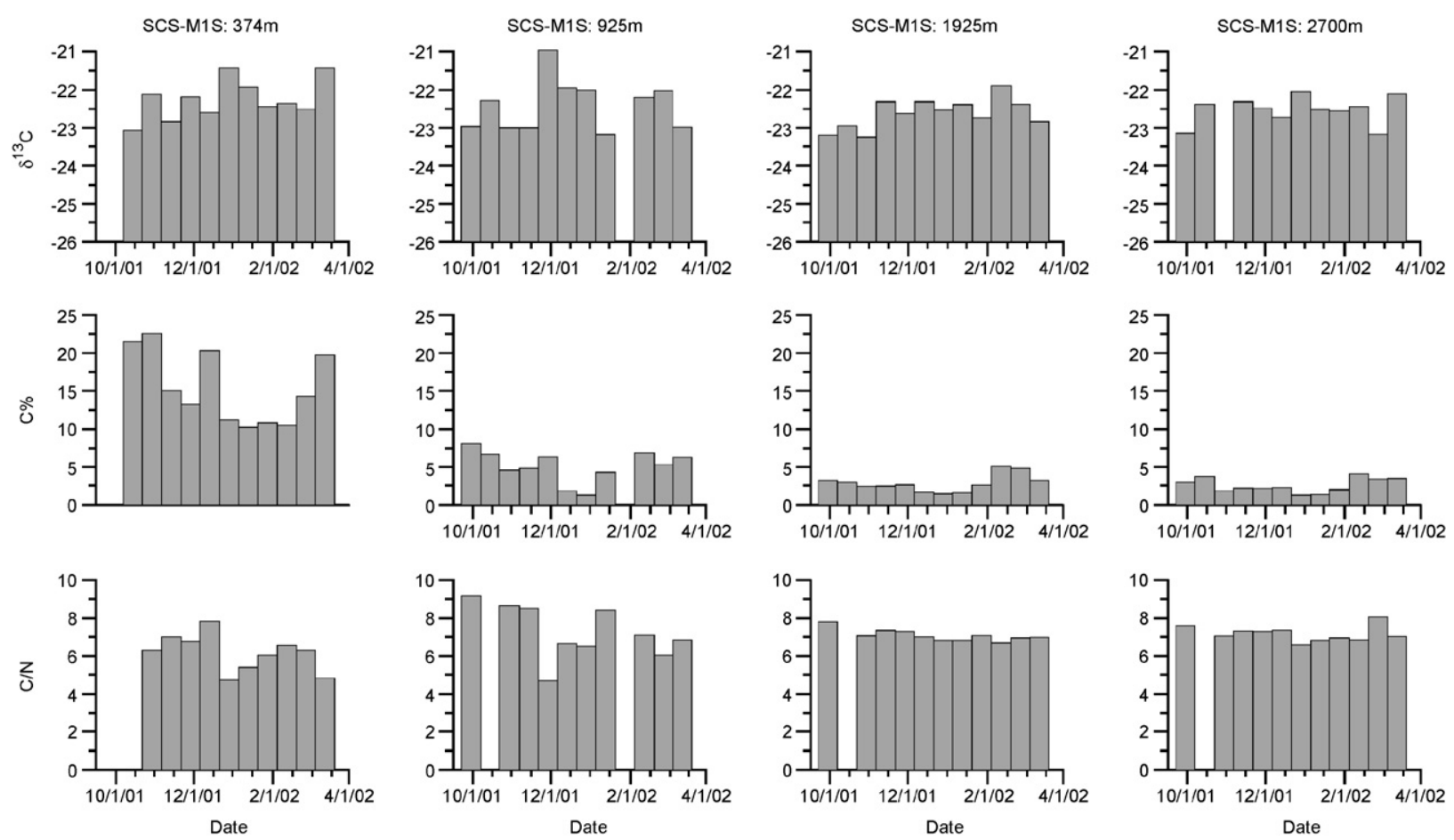

Fig. 6. Time-series of the $\delta^{13} \mathrm{C}$ value, the organic carbon content and the $\mathrm{C} / \mathrm{N}$ ratio of the decarbonated materials of samples collected by sediment traps deployed at depths of 374, 925, 1925 and $2700 \mathrm{~m}$ at Site M1S (Fig. 1) from September 22, 2001 to March 20, 2002. The sampling interval was 15 days per cup.

A simple mixing model based on $\mathrm{C} / \mathrm{N}$ ratio and $\delta^{13} \mathrm{C}$ of the POM is used to explore the contribution of terrigenous organic matter in sediment trap samples. It is assumed that the organic matter in sediment trap samples is a mixture of marine and terrigenous organic matter, which have distinctive $\mathrm{C} / \mathrm{N}$ ratios, $R_{\mathrm{m}}$ and $R_{\mathrm{t}}$, respectively, and $\delta^{13} \mathrm{C}$ values, namely, $\delta_{\mathrm{m}}$ and $\delta_{\mathrm{t}}$, respectively. Then both the $\mathrm{C} / \mathrm{N}$ ratio $(R)$ and the $\delta^{13} \mathrm{C}$ value $(\delta)$ of the mixture may be expressed as a function of the fraction of terrigenous organic matter $(f)$ as follows:

$R=R_{\mathrm{t}} f+(1-f) R_{\mathrm{m}}$,

$\delta=\left(f R_{\mathrm{t}} \delta_{\mathrm{t}}+(1-f) R_{\mathrm{m}} \delta_{\mathrm{m}}\right) / R$.

It is noted that the fraction of terrigenous organic matter is based on nitrogen contents so that it matches the $\mathrm{C} / \mathrm{N}$ ratio to make the calculation more straightforward.

The modeled mixing curves are shown in Fig. 10A. For the model calculation, the terrigenous end-member is assumed to have a uniform composition because of the relatively long distances of the two mooring sites from land, which may make terrigenous materials from different sources well mixed during transportation. For the marine endmember, both the $\delta^{13} \mathrm{C}$ value and the $\mathrm{C} / \mathrm{N}$ ratio are assumed to fluctuate within a range from a representative value. The compositions of the endmembers are so chosen that the mixing curves encompass most of the data points. The terrigenous end-member is assumed to have a $\mathrm{C} / \mathrm{N}$ ratio of 22 and $\delta^{13} \mathrm{C}$ value of $-25.5 \%$. The $\mathrm{C} / \mathrm{N}$ ratio of marine end-member is assumed to be $6.63 \pm 1$ and the $\delta^{13} \mathrm{C}$ value is assumed to be $-22.1 \pm 1.1 \%$. The inferred field of marine end-member composition coincides with the compositions of suspended POM to have the highest $\delta^{13} \mathrm{C}$ values (Fig. 10B). It is worth noting that the minimum $\mathrm{C} / \mathrm{N}$ ratio of the inferred marine end-member also coincides with the minimum of observed $\mathrm{C} / \mathrm{N}$ ratios of the suspended POM (Table 3, Fig. 10B).

The distribution of data points (Fig. 10A) shows characteristic differences between the two sites. Samples from Site M2S appeared to contain more terrigenous organic matter as indicated by the higher $\mathrm{C} / \mathrm{N}$ ratios and lower $\delta^{13} \mathrm{C}$ values. Samples from the deeper traps were more uniform in composition, but the same bias still existed. The site differences could be attributed to the circulation 

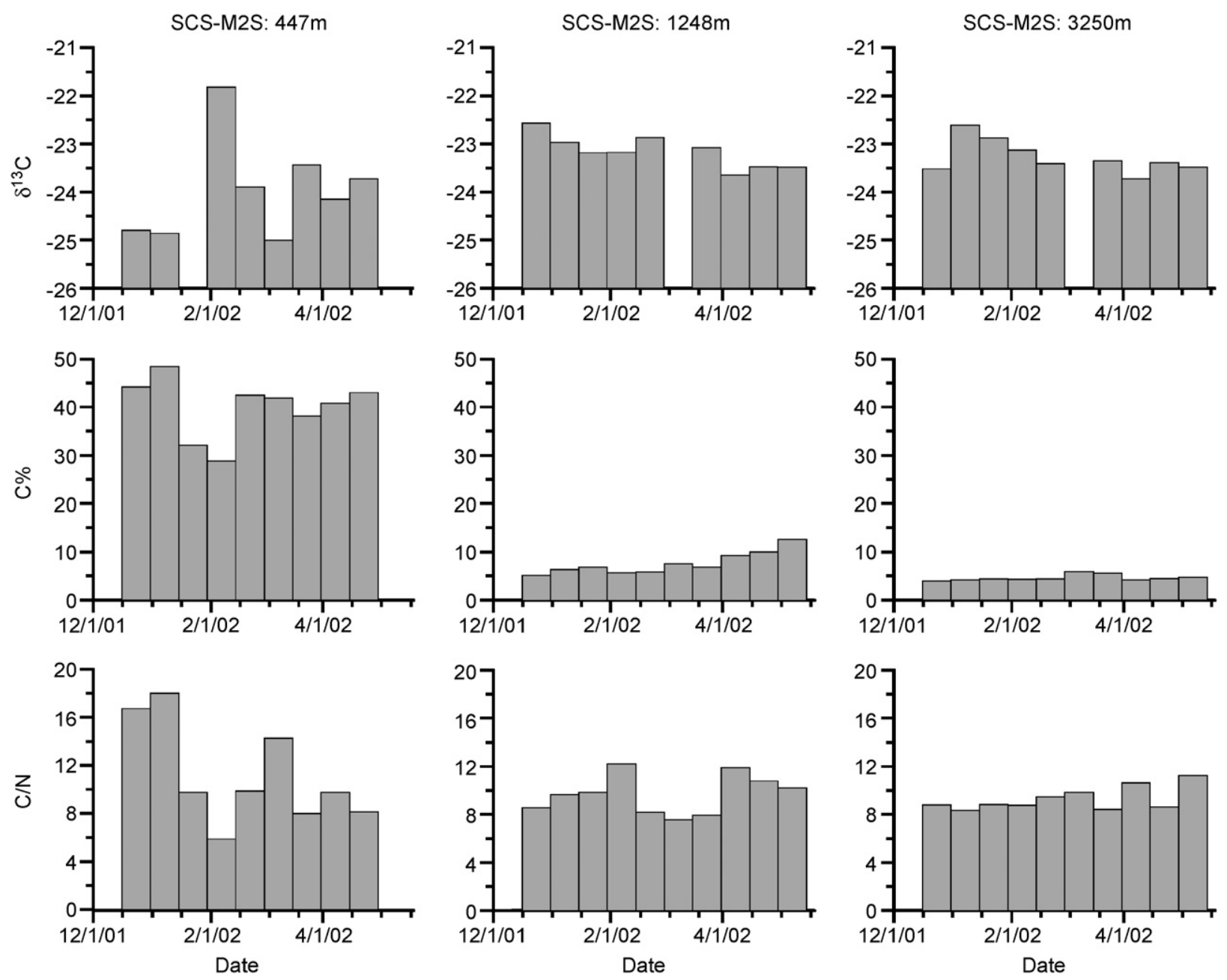

Fig. 7. The same as Fig. 6 except for traps deployed at 447, 1248 and $3250 \mathrm{~m}$ at Site M2S (Fig. 1) from December 16, 2001 to May 14, 2002.

pattern, which may have controlled the dispersion of re-suspended sediments. The higher $\mathrm{C} / \mathrm{N}$ ratios, implying stronger terrigenous signals, all occurred in winter, namely, from late December 2001 to early March 2002 (Fig. 7), coinciding with the trap deployment at both sites. The strong northeast monsoon (Liu et al., 2002) might have induced sediment re-suspension on the continental shelf northwest of the mooring sites of sediment traps and sustained seaward export of fine-grained sediments rich in terrigenous organic matter. However, the lack of the terrestrial signal in the trap samples from Site M1S, which was near the Luzon Strait, could be due to the intrusion of the Kuroshio (Wu and Chiang, 2007). In spite of the characteristic distinction of samples from the two sites, all data points follow the same mixing trend well (Fig. 10A).
It is also clear from the distribution of sea surface Chl- $a$ (Fig. 1B) that the two sites belong to the same biogeochemical regime (Fig. 1B). Therefore, we believe that the trap samples are representative of biogeochemical characteristics in the northern SCS proper and may reflect the biogeochemical processes occurring at the SEATS Station.

Applying the same mixing model to the composition of the suspended POM, we found that mixing of the terrigenous end-member with the inferred compositions of marine end-members can explain the compositional variations of only part of the samples. More than half of the POM data points cannot be accounted for by the mixing curves constructed for the trap samples. It is necessary to extend the lower limit of the $\delta^{13} \mathrm{C}$ value of the marine end-member to as low as $-26 \%$ to account 


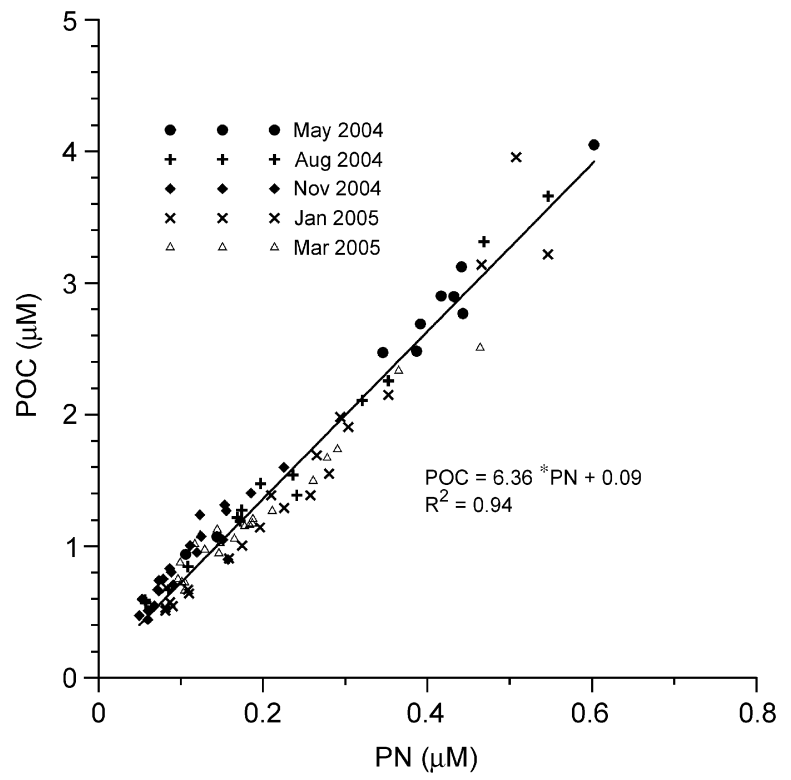

Fig. 8. Scatter plot of POC concentration vs. PN concentration obtained on the five cruises listed in Table 1. The line indicates the result of linear regression.

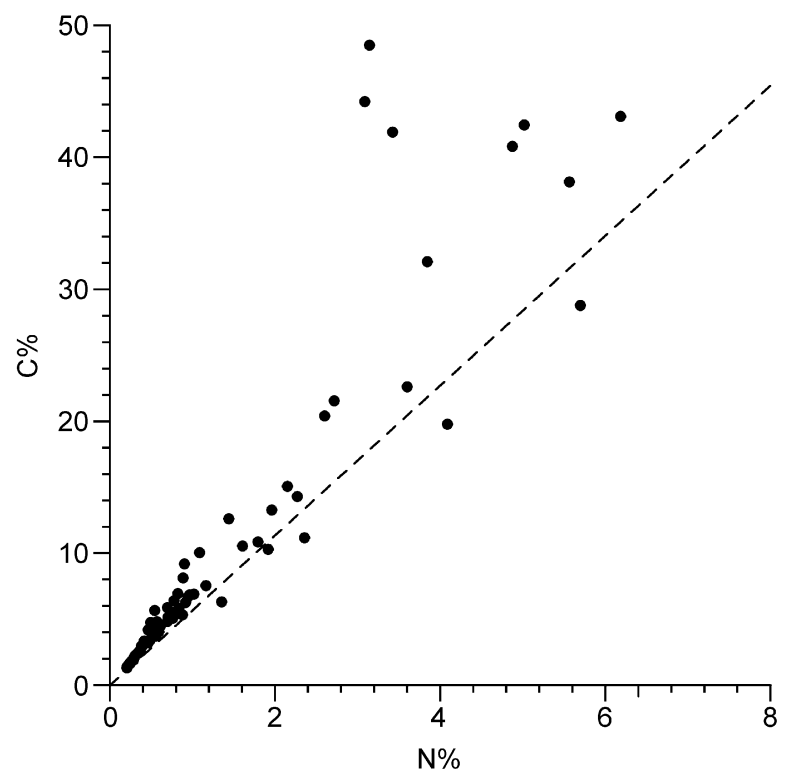

Fig. 9. Scatter plot of organic carbon content vs. nitrogen content in sediment trap samples. The line is a reference line indicating the Redfield ratio by weight.

for the entire observed compositional field. Additional controlling factors other than contribution of terrigenous organic matter are needed to explain the carbon isotopic variation.

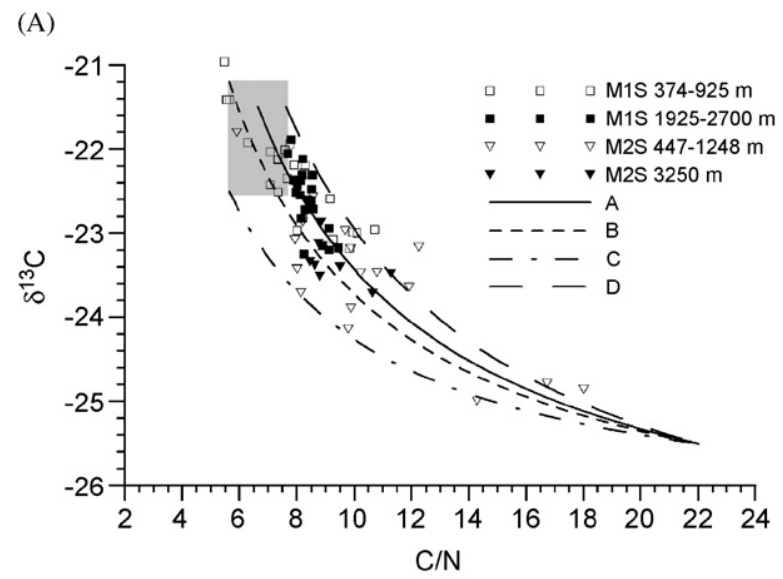

(B)

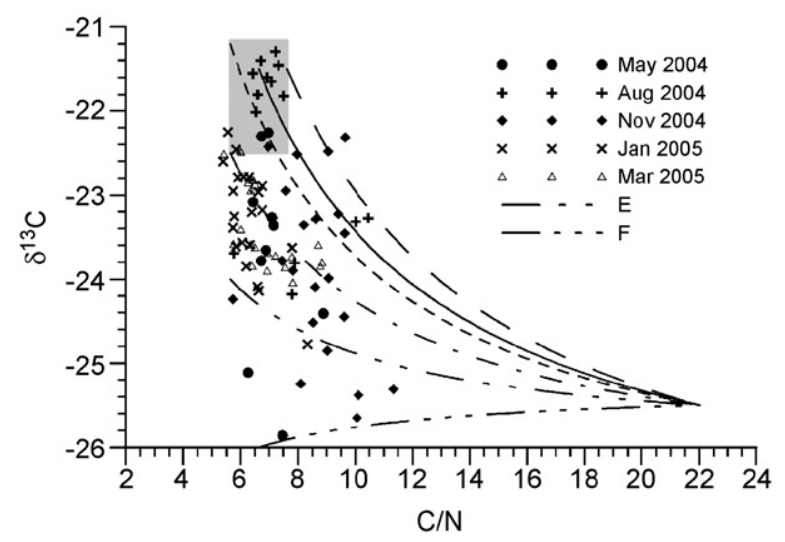

Fig. 10. (A) Scatter plot of the $\delta^{13} \mathrm{C}$ value of organic carbon in trap samples vs. $\mathrm{C} / \mathrm{N}$ ratio. The curves represent mixing between a terrigenous end-member $\left(\delta^{13} \mathrm{C}=-25.5 \%\right.$ and $\left.\mathrm{C} / \mathrm{N}=22\right)$ and marine end-members of different compositions, which are listed in Table 3 for different cases (see text). (B) The same as (A) except for the SPM samples.

Table 3

Compositions of the marine end-member used in the mixing model (see text)

\begin{tabular}{lll}
\hline Case & $\mathrm{C} / \mathrm{N}$ & $\delta^{13} \mathrm{C}(\%)$ \\
\hline $\mathrm{A}$ & 6.63 & -21.5 \\
$\mathrm{~B}$ & 5.63 & -21.2 \\
$\mathrm{C}$ & 5.63 & -22.5 \\
$\mathrm{D}$ & 7.63 & -21.5 \\
$\mathrm{E}$ & 5.63 & -24.0 \\
$\mathrm{~F}$ & 6.63 & -26.0 \\
\hline
\end{tabular}

\subsection{Control of carbon isotopic composition in phytoplankton}

The processes that control the carbon isotopic composition of POM produced by phytoplankton 
in the surface water have been extensively discussed (Rau et al., 1982, 1996; Hofmann et al., 2000). The fractionation between the carbon dioxide dissolved in the ambient aqueous medium, termed as aqueous $\mathrm{CO}_{2}$, and the product of photosynthesis is expressed as

$\alpha_{\mathrm{P}-\mathrm{aq}}=\left(1+\delta_{\mathrm{P}} / 1000\right) /\left(1+\delta_{\mathrm{aq}} / 1000\right)$,

where $\alpha_{\mathrm{P}}$ is the isotope fractionation factor, $\delta_{\mathrm{aq}}$ is the $\delta^{13} \mathrm{C}$ value of aqueous $\mathrm{CO}_{2}$, which is usually the major source of carbon during photosynthesis in aquatic environments, and $\delta_{\mathrm{P}}$ is the $\delta^{13} \mathrm{C}$ value of phytoplankton. The isotope fractionation factor is often replaced by the \%o fractionation defined as

$\varepsilon_{\mathrm{P}-\mathrm{aq}}=1000\left(\alpha_{\mathrm{P}-\mathrm{aq}}-1\right)$.

It is noted that the convention of the isotope fractionation parameters defined in this study follows that of Hofmann et al. (2000), which is different from that used by Rau et al. (1996), though the essence is the same.

The $\%$ fractionation, $\varepsilon_{\mathrm{P} \text {-aq }}$, has been found to be dependent mainly on the isotope fractionation during carbon fixation and the diffusive process in the aqueous medium (Rau et al., 1996). The higher the concentration of aqueous $\mathrm{CO}_{2}$ is, the stronger the fractionation gets. A simplified formulation is derived from previously proposed formulas as follows (Rau et al., 2001):

$\varepsilon_{\mathrm{P}-\mathrm{aq}}=\varepsilon_{\mathrm{P}-\mathrm{CO}_{2}}-\left\{\left(\varepsilon_{\mathrm{P}-\mathrm{CO}_{2}}+\varepsilon_{\mathrm{d}}\right) \mu_{\mathrm{i}} /\left[\mathrm{CO}_{2(\mathrm{aq})}\right]\right\}(\gamma / S) / P$,

where $\varepsilon_{\mathrm{P}-\mathrm{CO}_{2}}$ is the \%o fractionation during enzymatic carbon fixation, $\varepsilon_{\mathrm{d}}$ is the diffusive \%o fractionation of $\mathrm{CO}_{2}$ in seawater, $\mu_{\mathrm{i}}$ is the instantaneous specific growth rate $\left(\mathrm{s}^{-1}\right),\left[\mathrm{CO}_{2(\mathrm{aq})}\right]$ is the ambient concentration of aqueous $\mathrm{CO}_{2}, \gamma$ is the carbon content per cell (mol), $S$ is the surface area of the phytoplankton cell $\left(\mathrm{m}^{2}\right)$, and $P$ is the cell wall permeability $\left(\mathrm{m} \mathrm{s}^{-1}\right)$. The instantaneous specific growth rate is related to the $24 \mathrm{~h}$ specific growth rate $\left(\mu_{\mathrm{phy}}\right)$ by the following relationship:

$\mu_{\mathrm{i}}=(L+D) \mu_{\mathrm{phy}} / L$,

where $L$ and $D$ are the lengths of light and dark periods in a day. The length of the light period from sunrise to sunset at the SEATS Station varies from 11.07 to $13.13 \mathrm{~h}$ with an average of $12.05 \pm 0.8 \mathrm{~h}$. For practical reason, we assume the ratio $(L+D) / L$ to be 2.0. The carbon content per cell $(\gamma$, in mol C) is related to the cell volume $\left(V\right.$, in $\left.\mu \mathrm{m}^{3}\right)$ by the following relationship:

$\gamma=3.154 \times 10^{-14} \times V^{0.758}$.

The surface area of the phytoplankton cell is calculated from the radius $(r)$ of the cell, which is assumed to be spherical:

$S=4 \pi r^{2}$.

Because it is difficulty to determine the $\delta_{\mathrm{CO}_{2}}$ value directly, it may be calculated from $\delta_{\text {DIC }}$, the $\delta^{13} \mathrm{C}$ value of DIC, and the isotope fractionation factor between the aqueous $\mathrm{CO}_{2}$ and DIC. The isotope fractionation is defined as

$\alpha_{\text {aq-DIC }}=\left(1+\delta_{\text {aq }} / 1000\right) /\left(1+\delta_{\text {DIC }} / 1000\right)$.

The \%o fractionation, which is defined as 1000 $\left(\alpha_{\text {aq-DIC }}-1\right)$, was found to be a function of temperature and the second ionization fraction of carbonic acid (Zhang et al., 1995; Hofmann et al., 2000).

$\varepsilon_{\mathrm{aq}-\mathrm{DIC}}=-\left(0.0144\left[\mathrm{CO}_{3}^{2-}\right] /[\mathrm{DIC}]-0.1119\right) T-11.84$,

where $T$ is temperature $\left({ }^{\circ} \mathrm{C}\right)$.

The isotopic composition of the POC produced by phytoplankton may be calculated from that of the DIC and the overall \%o fractionation.

$$
\begin{aligned}
\delta_{\mathrm{P}} & =\left\{\left[\left(1+\delta_{\mathrm{DIC}} / 1000\right) \alpha_{\mathrm{P}-\mathrm{aq}} \alpha_{\mathrm{aq}-\mathrm{DIC}}\right]-1\right\} 1000 \\
& \approx \delta_{\mathrm{DIC}}+\varepsilon_{\mathrm{P}-\mathrm{aq}}+\varepsilon_{\mathrm{aq}-\mathrm{DIC}} .
\end{aligned}
$$

Therefore, the $\delta^{13} \mathrm{C}$ value of POC may be calculated by Eq. (13), which in turn needs input from Eqs. (7) and (12). The overall calculation depends on values of $\delta_{\text {DIC }}$, temperature $(T)$, aqueous $\mathrm{CO}_{2}$ concentration $\left(\left[\mathrm{CO}_{2(\mathrm{aq})}\right]\right)$ and the second ionization fraction of carbonic acid $\left(\left[\mathrm{CO}_{3}^{2-}\right] /[\mathrm{DIC}]\right)$ and a suite of variables listed in Table 4.

\subsection{Temporal variation of $\delta^{13} C_{P O C}$ in surface water}

Following the previous approach to explore isotopic variation of POC produced by phytoplankton in surface seawaters (Rau et al., 1997), we used Eq. (13) to calculate the $\delta^{13} \mathrm{C}$ value of POC in the surface water at SEATS under the hydrographic and chemical conditions observed on the five cruises. The purpose is to estimate the parameters of various processes controlling the isotopic composition of POC and to determine the major factors contributing to the observed isotopic variation of POC. 
Table 4

Values of parameters used for the calculation of $\delta^{13} \mathrm{C}$ values of POM produced by phytoplankton (see text)

\begin{tabular}{|c|c|c|c|c|c|c|}
\hline Parameter & Description & Value & Range & Units & $\begin{array}{l}\text { Sensitivity } \\
\text { (this study) }\end{array}$ & $\begin{array}{l}\text { Sensitivity } \\
\text { (Rau et al., 1997) }\end{array}$ \\
\hline$\mu_{\text {phy }}$ & $\begin{array}{l}\text { Twenty-four hour specific growth } \\
\text { rate of phytoplankton }\end{array}$ & 0.95 & $0.8-1.1$ & $d^{-1}$ & $8 \% \mathrm{~d}$ & $7 \% \mathrm{~d}$ \\
\hline$\varepsilon_{\mathrm{P}-\mathrm{CO}_{2}}$ & $\begin{array}{l}\text { Per-mil fractionation during } \\
\text { enzymatic carbon fixation }\end{array}$ & -23 & -25 to -21 & & $-0.6 \%$ & $-0.7 \%$ \\
\hline$\varepsilon_{\mathrm{d}}$ & $\begin{array}{l}\text { Diffusive isotope } \% \text { fractionation } \\
\text { of } \mathrm{CO}_{2} \text { in seawater }\end{array}$ & 0.7 & 0.7 & & & \\
\hline$r$ & $\begin{array}{l}\text { Mean cell radius of } \\
\text { phytoplankton }\end{array}$ & 1.5 & $0.85-2.6$ & $\mu \mathrm{m}$ & $1.4 \% \mu \mathrm{m}$ & $1.1 \%$ \\
\hline$P$ & $\begin{array}{l}\text { Cell wall permeability of } \\
\text { phytoplankton }\end{array}$ & $5 \times 10^{-5}$ & $4.3 \times 10^{-5}-6 \times 10^{-5}$ & $\mathrm{~m} \mathrm{~s}^{-1}$ & $-1.5 \times 10^{5} \% \mathrm{~m}^{-1} \mathrm{~s}$ & $-1.3 \times 10^{5} \% 0 \mathrm{~m}^{-1} \mathrm{~s}$ \\
\hline
\end{tabular}

In order to account for the co-variation of ambient conditions in the surface water, which is defined as the top $20 \mathrm{~m}$, we constructed time-series of temperature, $\left[\mathrm{CO}_{2}\right]_{\mathrm{aq}}, \delta_{\mathrm{DIC}}$ and $\left[\mathrm{CO}_{3}^{2-}\right] /[\mathrm{DIC}]$ by fitting polynomials to the observed data (Fig. 11). Using the time-series data, we calculated the $\delta^{13} \mathrm{C}_{\text {POC }}$ during the study period from May 2004 to March 2005 with different combination of parameter values for the calculation (Fig. 12). The base values and ranges of various parameters are listed in Table 4 . The base value of \%o fractionation during enzymatic carbon fixation $\left(\varepsilon_{\mathrm{P}-\mathrm{CO}_{2}}\right)$ was set to be $-23 \%$ following Hofmann et al. (2000). The base value of the cell wall permeability of phytoplankton $(P)$ was set to $5 \times 10^{-5} \mathrm{~ms}^{-1}$ following Rau et al. (1997). The base value of cell radius was set to $1.5 \mu \mathrm{m}$, which is considerably smaller than those used for the average oceanic conditions $(5-20 \mu \mathrm{m})$, because phytoplankters smaller than $3 \mu \mathrm{m}$ accounted for $77.6-90.1 \%$ of total Chl- $a$ concentration in the basin water of the northern SCS (Chen, 2005). The base value of $\mu_{\text {phy }}$ was set to $0.95 \mathrm{~d}^{-1}$, which is very close to the value of $1 \mathrm{~d}^{-1}$ used by Rau et al. (1997).

The curve of calculated $\delta^{13} \mathrm{C}_{\text {POC }}$ values based on the base values of the parameters appears to follow the trend of observed values (Fig. 12), but the amplitude of the observed variation is more pronounced than the calculated results. By varying the parameter values, one at a time, we were able to produce curves bracketing the observed values. The specific growth rate $\left(\mu_{\mathrm{phy}}\right)$ ranging from 0.8 to $1.1 \mathrm{~d}^{-1}$. In order to compare the range with observations, we plotted values of primary production vs. Chl- $a$ concentration in the top $20 \mathrm{~m}$ (Fig. 13) observed at a station (18.0N, 115.5E) very close to the SEATS Station (Chen, 2005). The specific growth rate $\left(\mu_{\text {phy }}\right)$ may be calculated from the following relationship:

$$
\begin{aligned}
\mu_{\text {phy }} & =\mathrm{PP} /\left[\mathrm{POC}_{\text {phy }}\right] \\
& =\mathrm{PP} /\left\{[\mathrm{Chl}-a](\mathrm{POC} / \mathrm{Chl}-a)_{\text {phy }}\right\},
\end{aligned}
$$

where $\mathrm{PP}$ is primary production in units of $\mathrm{mg} \mathrm{C} \mathrm{m}{ }^{-3} \mathrm{~d}^{-1}$, [ $\left.\mathrm{POC}_{\text {phy }}\right]$ is the phytoplankton biomass in units of $\mathrm{mg} \mathrm{m}^{-3}$, and (POC/Chl- $\left.a\right)_{\text {phy }}$ is the mean organic carbon to Chl- $a$ ratio of phytoplankton. Using the (POC/Chl- $a)_{\text {phy }}$ ratio of $50 \mathrm{mg} \mathrm{C} \mathrm{mg}^{-1}$ Chl- $a$ (Sarmiento et al., 1993), we calculated the specific growth rates from the data plotted in Fig. 13. The histogram of the calculated $\mu_{\text {phy }}$ values is shown in Fig. 13B. The range of the specific growth rate $\left(0.8-1.1 \mathrm{~d}^{-1}\right)$ that produced $\delta^{13} \mathrm{C}_{\mathrm{POC}}$ values bracketing the observed values coincides with the most frequently occurring observed values, lending support to the derived $\mu_{\mathrm{phy}}$ values.

Aside from the specific growth rate, other parameters also might contribute to the observed isotopic variability. It is demonstrated in Fig. 12B-D that similar curves bracketing the observed values may be produced by varying the other parameters. The sensitivities of the calculated $\delta^{13} C_{\text {POC }}$ value to the variation of the four parameters (Table 4) are similar to those found by Rau et al. (1997).

The sensitivity of the calculated $\delta^{13} \mathrm{C}_{\mathrm{POC}}$ value to the variation of the concentration of aqueous $\mathrm{CO}_{2}$ $\left(\left[\mathrm{CO}_{2}\right]_{\mathrm{aq}}\right)$ is explored by constructing a $\delta^{13} \mathrm{C}_{\mathrm{POC}}$ curve corresponding to $\left[\mathrm{CO}_{2}\right]_{\mathrm{aq}}$ in the range observed in the surface water at the SEATS Station with all parameters fixed at the base value and other variables fixed at the mean values in the top $20 \mathrm{~m}$ (Fig. 14). The constructed curve appears to follow 
(A)

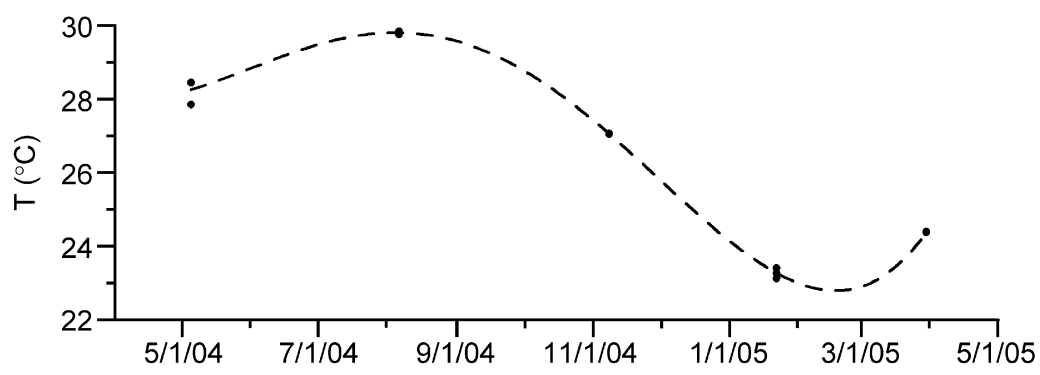

(B)

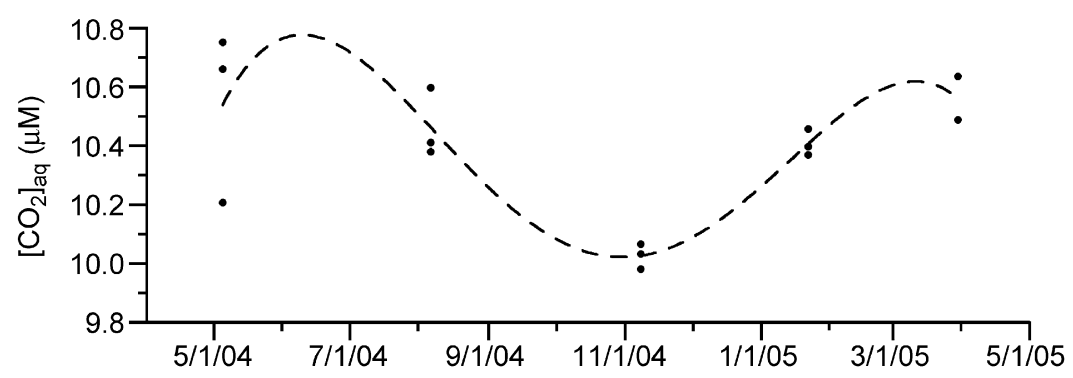

(C)

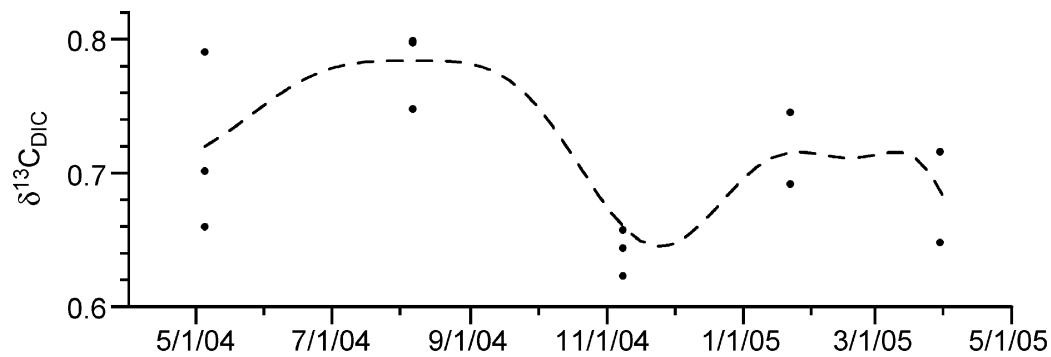

(D)

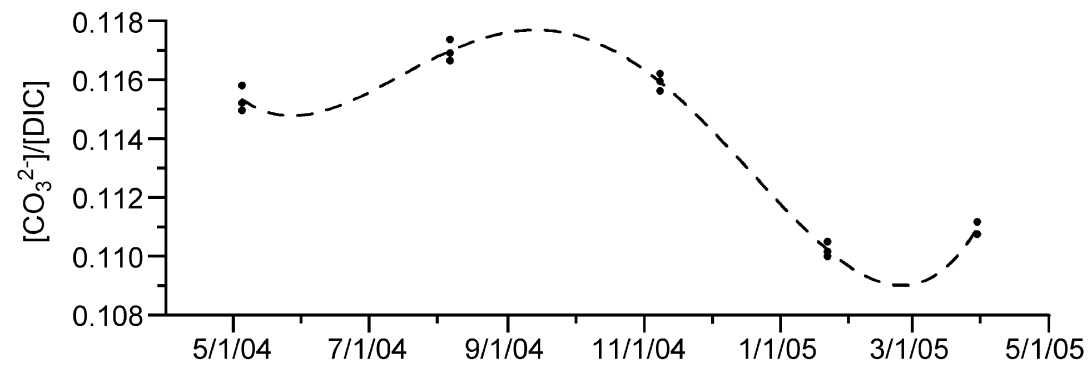

Fig. 11. Time-series of (A) temperature, (B) $\left[\mathrm{CO}_{2}\right]_{\mathrm{aq}}$, (C) $\delta^{13} \mathrm{C}_{\mathrm{DIC}}$ and (D) the second ionization fraction of carbonic acid in the top $20 \mathrm{~m}$ observed at the SEATS Station on the five cruises. The curves are polynomial fits of the data. The fit for $\delta^{13} \mathrm{C}_{\mathrm{DIC}}$ is based on the time-series fit of temperature and the temperature- $\delta^{13} \mathrm{C}_{\text {DIC }}$ relationship (not shown), which has a $R^{2}$ value of 0.68 , for optimization.

the trend manifested by the observed values except those from August 2004. The trend gives a sensitivity of $-0.75 \% \mu \mathrm{M}^{-1}$, which is slightly higher than that $\left(-0.6 \%{ }_{0} \mu \mathrm{M}^{-1}\right)$ reported by Rau et al. (1997). It is clear that the variation in $\left[\mathrm{CO}_{2}\right]_{\mathrm{aq}}$ contributes only about $0.5 \%$ to the overall variability of $\delta^{13} \mathrm{C}_{\mathrm{POC}}$.
4.4. Vertical variation of $\delta^{13} C_{P O C}$ in the upper water column

The vertical isotopic variation of POC in the SCS from the surface water to the surficial sediments is illustrated in Fig. 15. The accompanying distributions of the $\mathrm{C} / \mathrm{N}$ ratio of the suspended and the 
(A)

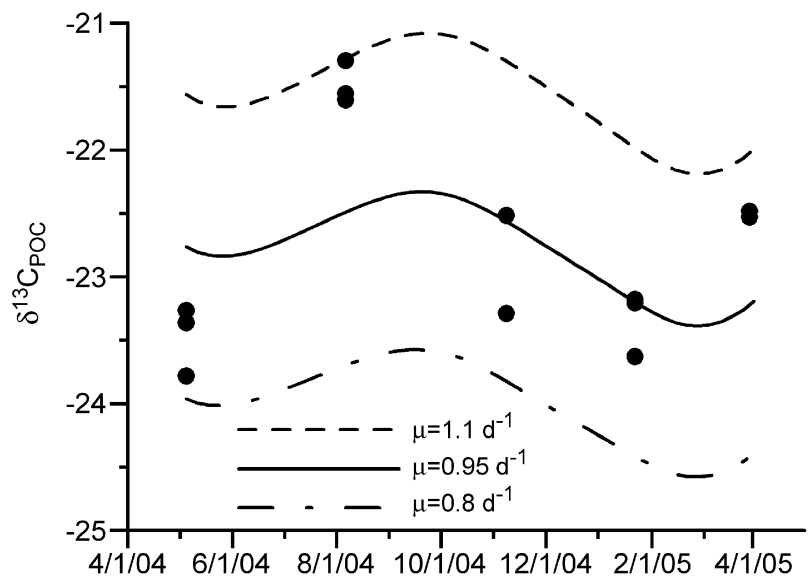

(C)

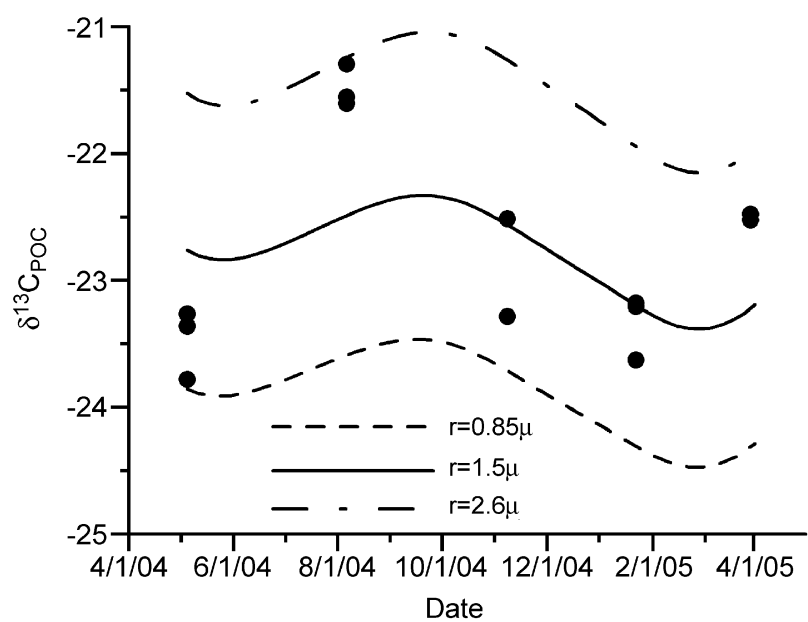

(B)

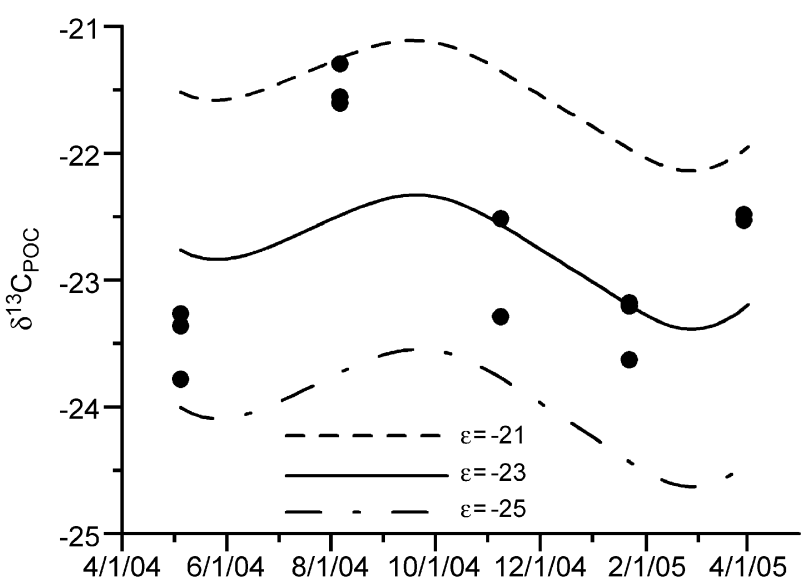

(D)

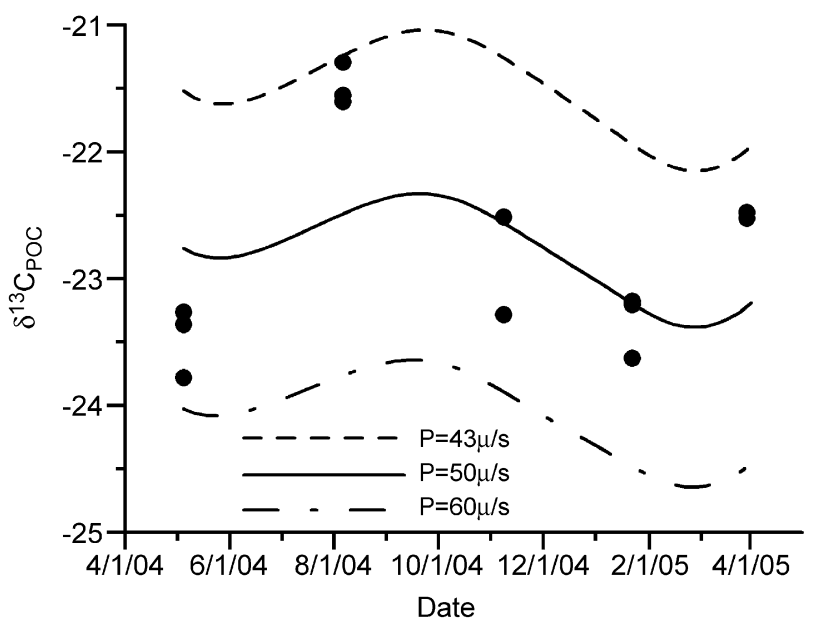

Fig. 12. Comparison between observed data and modeled time-series curves of the $\delta^{13} \mathrm{C}_{\mathrm{POC}}$ value from the top $20 \mathrm{~m}$ at the SEATS Station on the five cruises. (A) The solid curve is the modeled results calculated from time-series of variables shown in Fig. 11 and base values of

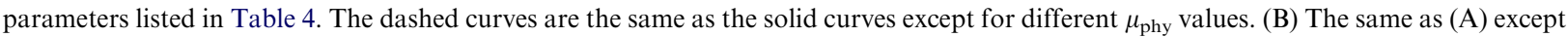
for different $\varepsilon_{\mathrm{P}-\mathrm{CO}_{2}}$ values. (C) The same as (A) except for different phytoplankton radii. (D) The same as (A) except for different cell membrane permeability.

sinking POM in the northern SCS are shown in Fig. 16. The suspended POC in the upper $200 \mathrm{~m}$ showed a decreasing trend of the $\delta^{13} \mathrm{C}$ value. The concentration-weighted mean $\delta^{13} \mathrm{C}$ value decreased from $-22.1 \%$ in the top $20 \mathrm{~m}$ to $-23.0 \%$ in the 21-100 m layer to $-24.0 \%$ in the $101-200 \mathrm{~m}$ layer. As shown in Fig. 16, the ranges of the $\mathrm{C} / \mathrm{N}$ ratio is quite narrow in the top $100 \mathrm{~m}$ with the concentration weighted mean values, 6.2 for $0-21 \mathrm{~m}$ and 6.5 for $21-100 \mathrm{~m}$, very close to the Redfield ratio of 6.67. Deeper than $100 \mathrm{~m}$ the $\mathrm{C} / \mathrm{N}$ ratio tends to increase, suggesting the presence of terrigenous POC, but the weighted mean, 7.3 for $101-200 \mathrm{~m}$, is only slightly higher than the Redfield ratio, indicating limited terrestrial contribution. We have demon- strated earlier (see Fig. 10) that the decreasing trend of $\delta^{13} \mathrm{C}_{\mathrm{POC}}$ with depth cannot be satisfactorily explained by contribution of terrigenous POC. What has caused the vertical variation of isotopic composition of suspended POC in the upper water column is worth further discussion.

In the subsurface water from 21 to $200 \mathrm{~m}$, some of the observed $\delta^{13} \mathrm{C}_{\mathrm{POC}}$ values were significantly lower than those observed in the surface water. It has been reported before that $\delta^{13} \mathrm{C}_{\mathrm{POC}}$ profiles usually show a minimum in the pycnocline (Jeffrey et al., 1983). The depths of the pycnocline at the SEATS Station were in the range of $50-150 \mathrm{~m}$, as exemplified by the hydrographic profiles in Figs. 2 and 3 , where the $\delta^{13} \mathrm{C}_{\mathrm{POC}}$ values were indeed the 


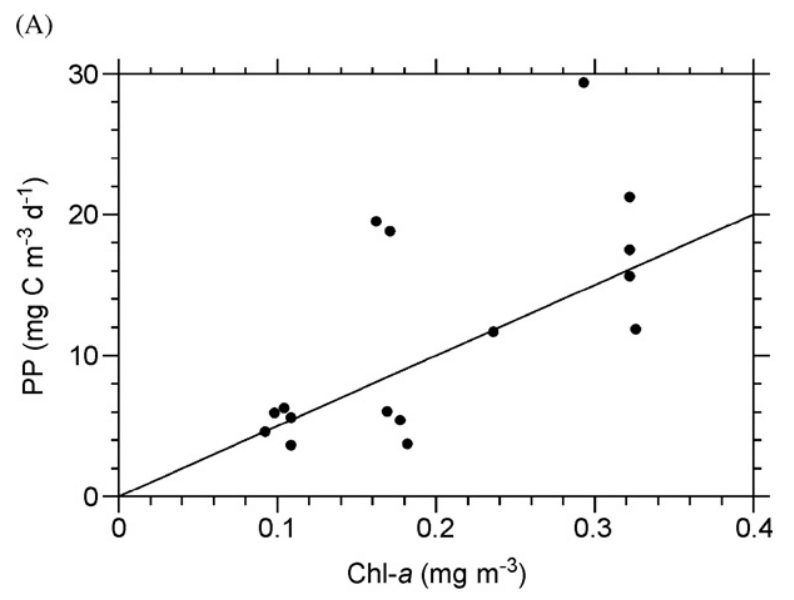

(B)

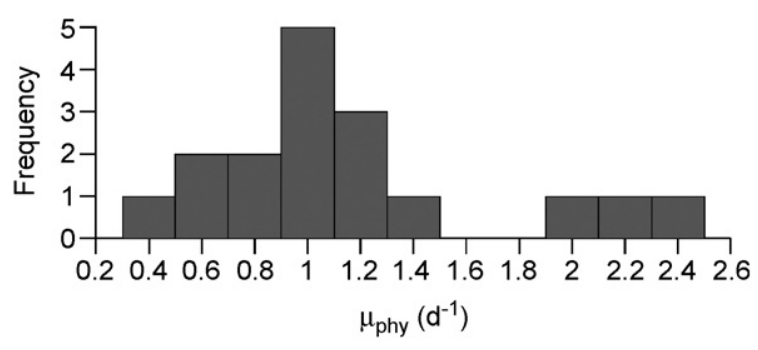

Fig. 13. (A) Scatter plot of primary production vs. Chl- $a$ concentration observed at a station very close to the SEATS Station (Chen, 2005). These data allow us to calculate the specific growth rates (see text). The line indicates the specific growth rate of $1 \mathrm{~d}^{-1}$. (B) The histogram of the specific growth rates calculated form the data shown in (A). lowest. The depletion of ${ }^{13} \mathrm{C}$ is attributed to biological reworking of $\mathrm{POC}$ in the pycnocline (Jeffrey et al., 1983), where the settling of the particles may slow down due to increasing density of the seawater and respiration may be enhanced. The trend appears to agree with the diagenetic isotopic change observed for the residual of aquatic vascular plants, namely, Spartina grass, which showed relatively large decreases, up to $4 \%$, of $\delta^{13} \mathrm{C}_{\text {org }}$ values during degradation (Benner et al., 1987). The isotopic alteration is attributed to preferential preservation of lignin, which is isotopically light, in the plant detritus. It also agrees with results of incubation experiments on lacustrine biomass (Lehmann et al., 2002), which showed a decrease of $\delta^{13} \mathrm{C}_{\text {POC }}$ up to $1.5 \%$ during degradation. However, none of these experiments were conducted for algal materials from the open ocean. In other words, direct evidence of carbon isotopic shift toward lighter values during degradation of biogenic POM in the water column of the open ocean is lacking. Therefore, there could be other explanation for the decreasing trend of $\delta^{13} \mathrm{C}_{\mathrm{POC}}$ observed in the water column at SEATS and other oceanic regions.

It is proposed here that the changing isotope fractionation during production of POC at different depths, instead of biological degradation, may have contributed to the decreasing trend of $\delta^{13} \mathrm{C}_{\mathrm{POC}}$ in the subsurface water column. Because of the

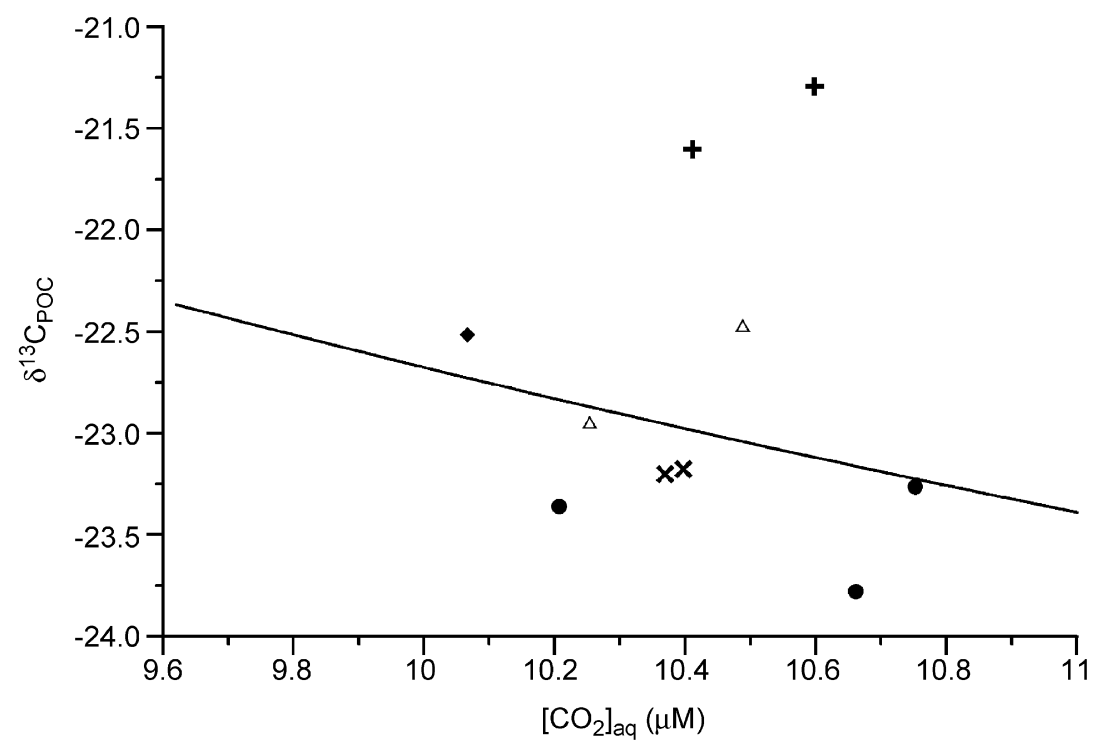

Fig. 14. The scatter plot of $\delta^{13} \mathrm{C}_{\mathrm{POC}}$ vs. $\left[\mathrm{CO}_{2}\right]_{\mathrm{aq}}$ observed at the SEATS Station on the five cruises. The line indicates the modeled results calculated by Eq. (13) using the mean values of all variables in the surface layer except the $\left[\mathrm{CO}_{2}\right]_{\mathrm{aq}}$ value, which varied in the plotted range, and the base values of the parameters listed in Table 4 . 


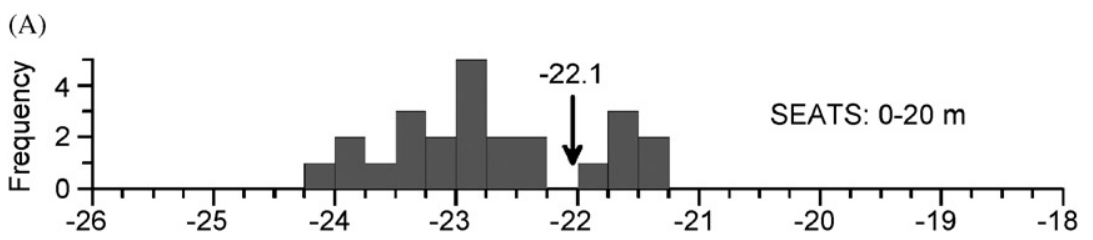

(B)

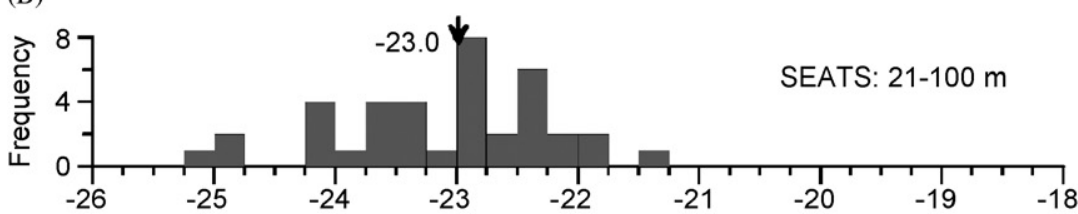

(C)

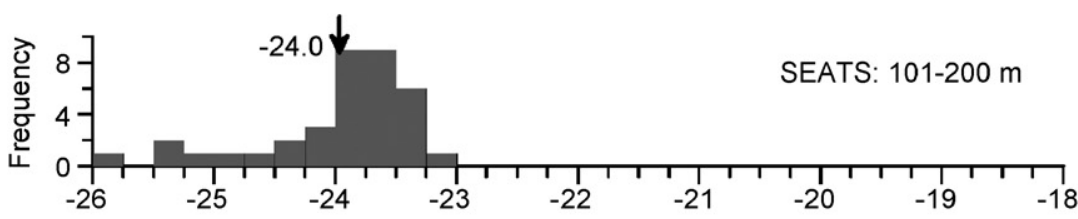

(D)

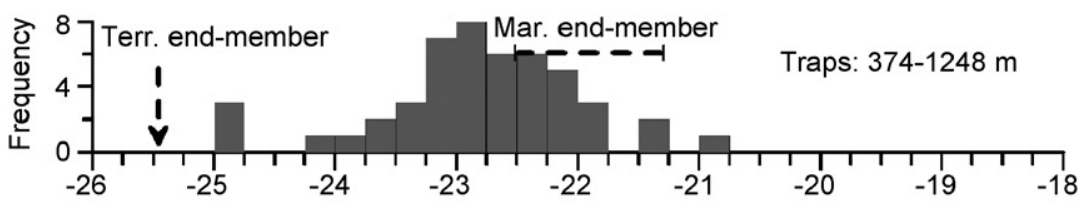

(E)

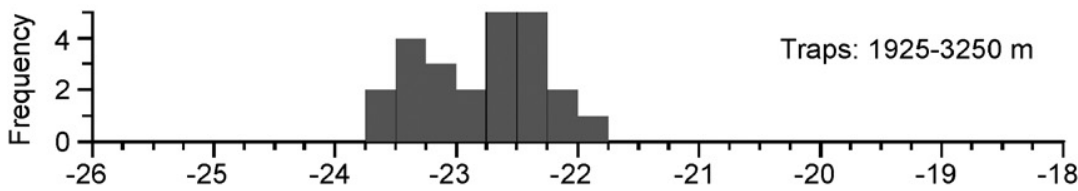

(F)

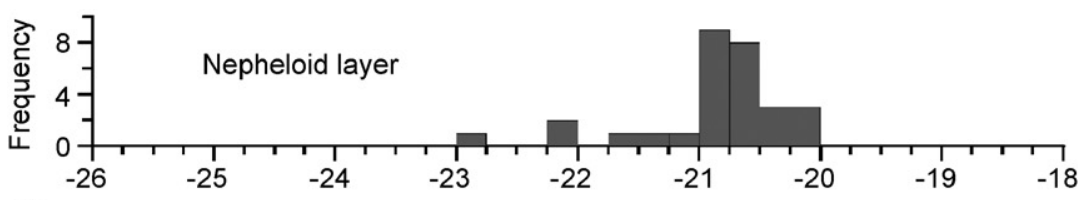

(G)

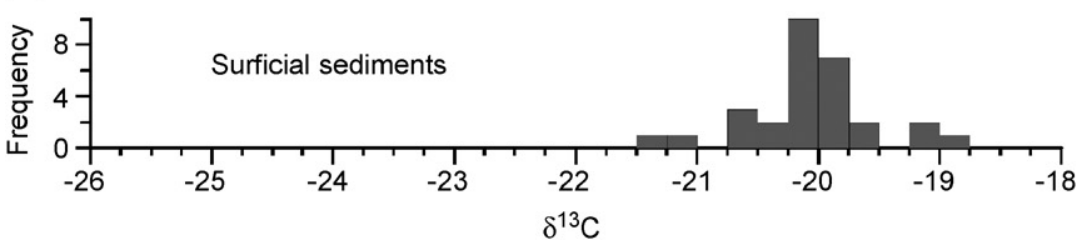

Fig. 15. Histogram of the $\delta^{13} \mathrm{C}$ values of organic carbon in different types of samples from different depths in the SCS. The solid arrows indicate the concentration-weighted mean values (see text).

oligotrophic condition in the SCS (Liu et al., 2002), the euphotic zone is pretty thick. For the euphotic zone depth defined as the depth at which the photosynthetically active radiance is reduced to $0.6 \%$ of the surface value, it was found in the northern SCS basin to be about $100 \mathrm{~m}$ in winter (Chen et al., 2004). It is also known that the Chl- $a$ concentration in the SCS in winter is generally higher than in other seasons (Liu et al., 2002; Tseng et al., 2005; Chen, 2005). Therefore, the euphotic 

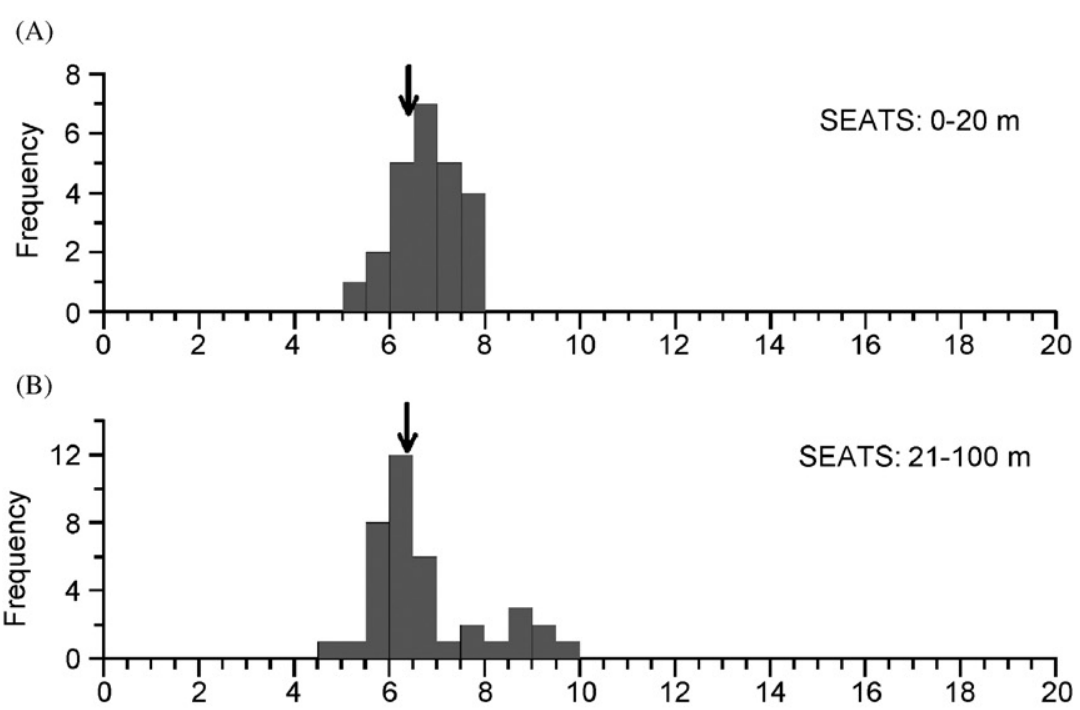

(C)

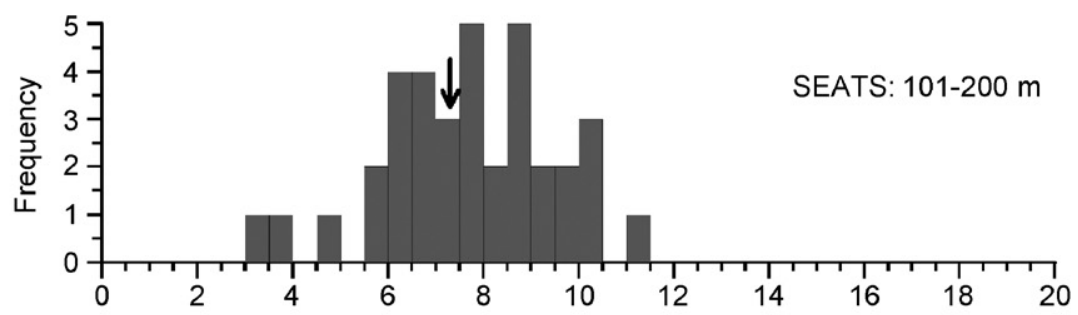

(D)

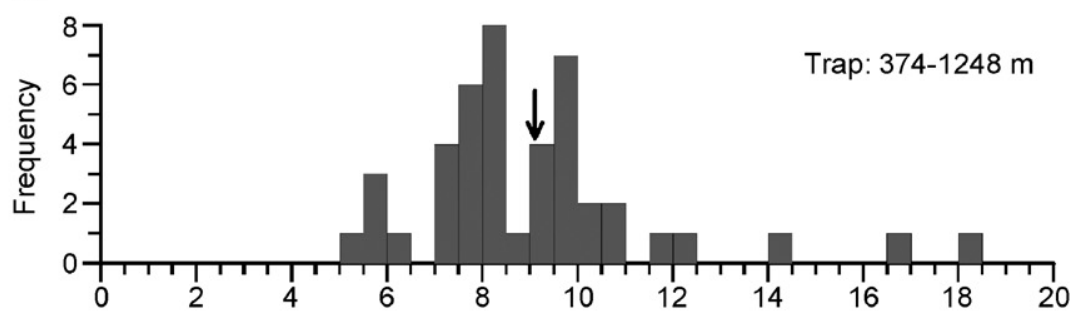

(E)

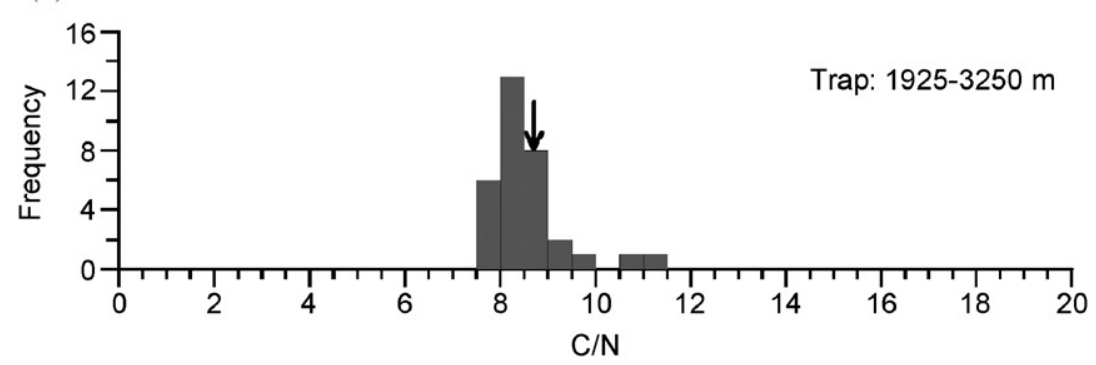

Fig. 16. Same as Fig. 15 except for $\mathrm{C} / \mathrm{N}$ ratio. It is noted that sedimentary samples are not included due to lack of data.

zone depths in other seasons should be deeper than $100 \mathrm{~m}$. The specific growth rates in the top $100 \mathrm{~m}$, which were calculated in the same manner described earlier, decreased rapidly with depth below the top $20 \mathrm{~m}$ (Fig. 17A). Its depth dependency may be expressed as the following equation:

$$
\begin{aligned}
\mu_{\text {phy }}= & 3.0 \exp [-0.07(z-2)] \\
& \times\{1-\exp [-0.08(z+4)]\}+0.1,
\end{aligned}
$$

where $\mu_{\text {phy }}$ is in units of $\mathrm{d}^{-1}$ and $z$ is depth (m). 
(A)

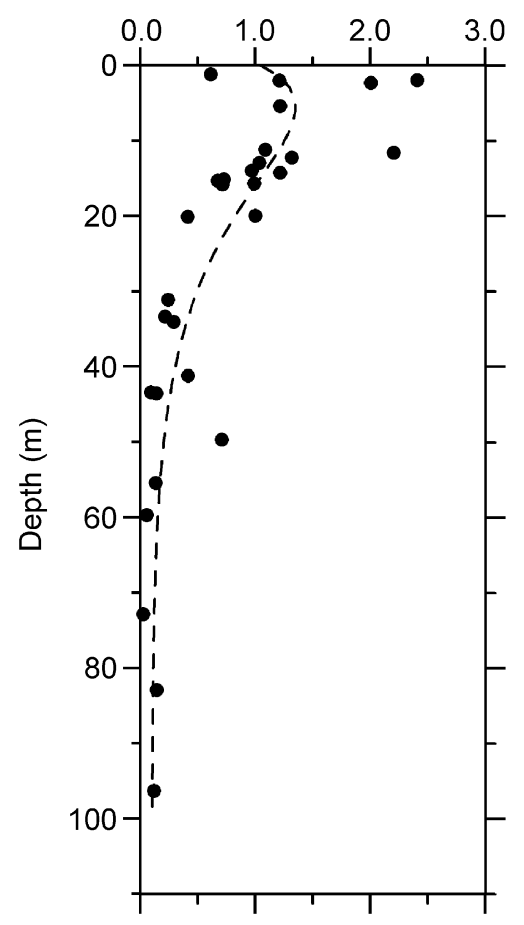

(B)

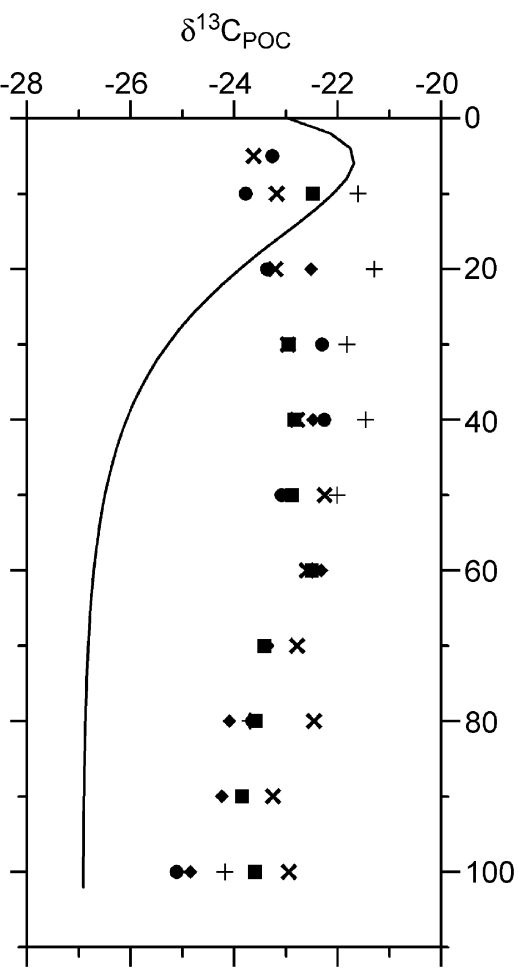

Fig. 17. (A) Calculated specific growth rates from previously reported data of primary production and Chl- $a$ concentration at a station very close to the SEATS Station (Chen, 2005). The curve is the fit of the data. (B) Observed and modeled $\delta^{13} \mathrm{C}_{\mathrm{POC}}$ values in the top $100 \mathrm{~m}$ at SEATS (see text). The curve is the modeled results, which were based on the specific growth rates represented by the fitted curve in (A).

Assuming the same mechanism represented by Eq. (13) also governed the isotopic fractionation in the subsurface water column, we calculated the $\delta^{13} \mathrm{C}_{\text {POC }}$ profile in the top $100 \mathrm{~m}$ (Fig. 17B). For the calculation, we employed Eq. (15) to estimate the specific growth rate, adopting the base values listed in Table 4 for all other parameters and using mean values of variables in the surface layer for all depths. In other words, the calculated results reflect only the effect of changing $\mu_{\text {phy }}$ on the isotopic composition of POC produced by phytoplankton. It is clear that very light POC may be produced in the subsurface water column due to decreasing $\mu_{\mathrm{phy}}$. In fact, the calculated $\delta^{13} \mathrm{C}_{\mathrm{POC}}$ values in the subsurface layer are much lower than the observed values, suggesting that the subsurface POC was a mixture of in situ produced POC and the POC produced in the surface water, where primary productivity is the highest (Chen, 2005). The decreasing trend of $\delta^{13} \mathrm{C}_{\mathrm{POC}}$ in the subsurface water could be mainly due to increasing contribution of isotopically light POC produced in the lower euphotic zone.

\subsection{Relationship between suspended and sinking POM}

To extend our discussion further down the water column, we explore the isotopic variation of the sinking and sedimentary organic matter with respect to that of the suspended POM. The sedimentary records from the SCS were reported by Kienast et al. (2001). Though the sampling localities of the fluff materials and the surface sediments distribute in a large area of the SCS (Fig. 1B), they all fall within the region of rather low average sea-surface Chl- $a$ level, which also includes the SEATS Station and the two sediment trap sites. In light of the widely applied biogeochemical characterization based on ocean color (e.g., Longhurst et al., 1995), we have good reason to believe that the average biogeochemical conditions of these sites are similar and the comparison of the isotopic compositions of organic carbon from these sites is meaningful.

Contrary to the decreasing trend with depth in the top $200 \mathrm{~m}$, the $\delta^{13} \mathrm{C}$ values of particles collected in sediment traps deployed at depths deeper than 
$200 \mathrm{~m}$ became higher than those values observed in the subsurface water (Fig. 15). On the other hand, the trend of increasing $\mathrm{C} / \mathrm{N}$ ratio in the top $200 \mathrm{~m}$ continued in the deeper water as recorded by the sediment traps reaching a maximum in the depth range of $374-1248 \mathrm{~m}$ (Fig. 16). As demonstrated earlier (Figs. 7 and 10A), the trap samples, especially those from the intermediate depths of $447-1248 \mathrm{~m}$ at Site M2S, contained a significant amount of terrigenous organic matter. The significant contribution of terrigenous organic matter in the intermediate depths is consistent with the notion of seaward export of re-suspended materials from the continental shelf. Intermediate nepheloid layers between 600 and $1440 \mathrm{~m}$ have been observed in the Bay of Biscay during the OMEX project (McCave et al., 2001). In spite of the terrigenous contribution, we have successfully derived the carbon isotopic composition of the marine end-member for the organics in sediment trap samples (Fig. 10A). Its inferred range of the $\delta^{13} \mathrm{C}$ value, $-22.5 \%$ to $-21.3 \%$, overlaps significantly with the range observed in the surface layer $(0-20 \mathrm{~m})$ and the mid value $(-22.1 \%)$ of the inferred range coincides with the concentration-weighted mean of $\delta^{13} \mathrm{C}$ value in the surface layer (Fig. 15). This indicates that the sinking POC is mainly contributed by the highly productive surface layer.

It has been shown that the organic carbon in fluff samples above seafloor in the SCS (Kienast et al., 2001) is more enriched in ${ }^{13} \mathrm{C}$ with respect to the suspended POC in the surface water and the inferred marine end-members in sinking particles (Fig. 15); moreover, the surface sediments in turn have higher $\delta^{13} \mathrm{C}_{\text {org }}$ than the fluff samples. Such progressive enrichment in ${ }^{13} \mathrm{C}$ may be attributed to the preferential removal of ${ }^{12} \mathrm{C}$ during degradation of POM (Westerhausen et al., 1993). However, observations in the Cariaco Basin did not show significant changes in the $\delta^{13} \mathrm{C}_{\mathrm{POC}}$ values between sediment traps deployed at different depths, suggesting insignificant isotopic fractionation during diagenesis in the water column (Woodworth et al., 2004). On the other hand, it has been proposed that the lower $\delta^{13} \mathrm{C}_{\mathrm{POC}}$ values in fluff samples than the sedimentary organics is attributed to the Suess effect, i.e. the invasion of the isotopically light anthropogenic $\mathrm{CO}_{2}$ into the ocean (Kienast et al., 2001). The Suess effect observed in the SCS may cause the $\delta^{13} \mathrm{C}_{\text {DIC }}$ value to change by $-0.026 \%$ for an increase of DIC by $1 \mu \mathrm{mol} \mathrm{kg}-1$. SW (Chou, 2004; Chou et al., 2007). The increase of
DIC concentration in the surface water of the SCS was estimated to be about $60 \mu \mathrm{mol} \mathrm{kg}{ }^{-1}$-SW on average (Chou, 2004; Chou et al., 2007) and the average change in $\delta^{13} \mathrm{C}_{\text {DIC }}$ was estimated to be about $-1.6 \%$.

In addition to the Suess effect, the elevated concentration of aqueous $\mathrm{CO}_{2}$ in the surface water resulting from increasing $\mathrm{CO}_{2}$ partial pressure may also further depress the $\delta^{13} \mathrm{C}_{\mathrm{POC}}$ in the present day ocean. For the sake of discussion, we estimated concentrations of DIC and carbonate species during pre-industrial era in the SCS surface water corresponding to the five sampling conditions obtained in this study by assuming the same total alkalinity for each case but a reduced $\mathrm{CO}_{2}$ partial pressure of $280 \mu \mathrm{atm}$ (Petit et al., 1999). The calculation showed that concentrations of aqueous $\mathrm{CO}_{2}$ in the pre-industrial era had been only $75 \%$ of the current values on average and the second ionization fractions of carbonic acid had been about $23 \%$ higher than the current values due to higher $\mathrm{pH}$. Then we calculated the $\delta^{13} \mathrm{C}_{\mathrm{POC}}$ values by using the same values of the variables and parameters for the modern cases except the carbonate species and the $\delta^{13} \mathrm{C}_{\text {DIC }}$ values which were assigned with the aforementioned values. The resultant pre-industrial $\delta^{13} \mathrm{C}_{\mathrm{POC}}$ values had been higher than the current values by $3.5-4.3 \%$. Qualitatively these estimates support the notion that the isotopic differences between the currently produced POC and the organic carbon in surficial sediments reflect the actual changes in time; quantitatively, the estimated differences are significantly larger than the observed differences of $2-3 \%$ o (Fig. 15).

There are several factors that may cause the discrepancy. Firstly, the dissolved $\mathrm{CO}_{2}$ in the SCS surface water was assumed to be equilibrated with the atmospheric $\mathrm{CO}_{2}$ with an average partial pressure of $280 \mu \mathrm{atm}$ (Petit et al., 1999), but the actual situation could have been slightly supersaturated due to the input of terrigenous organic carbon. Secondly, the sea surface temperatures were assumed to be the same as the present time, but the pre-industrial era, especially from 15 to 19th century, was cooler than today (Folland et al., 2001). According to a previous study (Rau et al., 1997), the temperature has a positive effect on the $\delta^{13} \mathrm{C}_{\mathrm{POC}}$ of $0.4 \%{ }^{\circ} \mathrm{C}^{-1}$. Slight supersaturation of $\mathrm{CO}_{2}$ and/or lower sea surface temperature may reduce the estimated differences to the observed level. 


\section{Summary and conclusions}

On the five cruises from May 2004 to March 2005 to the SEATS Station, the observed $\delta^{13} \mathrm{C}$ value of suspended POC varied from $-24.2 \%$ to $-21.3 \%$ in the top $20 \mathrm{~m}$, from $-25.1 \%$ to $-21.5 \%$ in the $21-100 \mathrm{~m}$ layer, and from $-25.9 \%$ to $-23.2 \%$ in the 101-200 m layer. The organic carbon in sediment trap samples collected from September 2001 to May 2002 in northern SCS had $\delta^{13} \mathrm{C}$ values ranging from $-25.0 \%$ to $-21.0 \%$ for traps deployed between 374 and $1248 \mathrm{~m}$ and from $-23.7 \%$ to $-21.9 \%$ for traps deployed between 1925 and $3250 \mathrm{~m}$. The $\mathrm{C} / \mathrm{N}$ ratios of sediment trap samples reached as high as 18 , indicating contribution of terrigenous organic matter, which occurred mainly in the depth range of $450-1300 \mathrm{~m}$. A mixing model depicting the relationship between the $\delta^{13} \mathrm{C}$ value and $\mathrm{C} / \mathrm{N}$ ratio of POM revealed that the organic matter in sediment trap samples were mixtures of terrigenous organics with $\delta^{13} \mathrm{C}$ value of $-25.5 \%$ and $\mathrm{C} / \mathrm{N}$ ratio of 22 and marine organics with $\delta^{13} \mathrm{C}$ values from $-22.5 \%$ to $-21.3 \%$ and $\mathrm{C} / \mathrm{N}$ ratios from 5.6 to 7.6 . The same mixing model revealed that the suspended POM from the SEATS Station contained minor amount of terrigenous organic matter, and the observed range of $\delta^{13} \mathrm{C}_{\mathrm{POC}}$ values reflected the actual isotopic variability of marine organic matter.

Simulation of the carbon isotopic composition of phytoplankton in the surface water based on observed values of hydrographic and chemical variables may match the observed range of $\delta^{13} \mathrm{C}_{\mathrm{POC}}$ values in the top $20 \mathrm{~m}$, while variations in the biological parameters, including the specific growth rate, enzymatic isotope fractionation during carbon fixation, cell size and cell wall permeability, within the normal ranges may have contributed significantly to the observed isotope variability. If the same processes controlling the carbon isotopic composition of phytoplankton in the surface water worked in the entire euphotic zone of about $100 \mathrm{~m}$ thick, isotopically very light POC with $\delta^{13} \mathrm{C}_{\mathrm{POC}}$ as low as $-28 \%$ could have been produced in the subsurface layer due to the exponentially decreasing specific growth rate. Therefore, the observed decreasing trend of $\delta^{13} \mathrm{C}_{\mathrm{POC}}$ below the surface layer down to $200 \mathrm{~m}$ could have resulted from addition of the isotopically very light POC produced in the subsurface water to the isotopically normal POC produced in the surface layer.

The marine component in the sinking POM collected in sediment traps had a mid $\delta^{13} \mathrm{C}$ value
$(-22.1 \%)$ coinciding with the concentration weighted mean $\delta^{13} \mathrm{C}_{\mathrm{POC}}$ value in the top $20 \mathrm{~m}$, suggesting the surface layer as the dominant source of sinking POC. However, the inferred $\delta^{13} \mathrm{C}$ values of the marine end-member of the sinking POM are significantly lower than those $(-22.8 \%$ to $-20.1 \%$ ) of the POM in the nepheloid layer above seafloor in the SCS, which are in turn lower than those $(-21.3 \%$ to $-19.0 \%)$ of organic matter in surficial sediments from the SCS. It cannot be excluded that preferential removal of ${ }^{12} \mathrm{C}$ during degradation of POM accounts for the progressive enrichment of ${ }^{13} \mathrm{C}$ during settling and deposition of organic matter. However, according to a calculation, the relative depletion of ${ }^{13} \mathrm{C}$ in the more recent samples, namely the POM in the surface water and the nepheloid layer, with respect to the organic carbon in surficial sediments is attributable to two factors: (1) the drop of $1.6 \%$ in the isotopic composition of DIC attributed to the Suess effect, and (2) the increasing concentration of aqueous $\mathrm{CO}_{2}$ and other related changes in carbonate species that favor isotopic fractionation against incorporation of ${ }^{13} \mathrm{C}$ during carbon fixation. The overall effect is more than enough to account for the observed isotopic differences. Therefore, this study supports the notion that the isotopic composition of deposited organic carbon in the SCS can faithfully reflect the $\mathrm{CO}_{2}$ chemistry in the surface water, but considerable isotopic variation may be induced by changes in hydrographic and biological conditions. In other words, isotope fractionation during degradation of POM may not be ruled out as a possible mechanism for the observed vertical variation in the $\delta^{13} \mathrm{C}_{\mathrm{POC}}$ value, but its importance in controlling the $\delta^{13} \mathrm{C}$ value of deposited organic carbon is not warranted. More studies focused on the production of POM in the surface water and relationship between the freshly produced POM in the upper water column and the sinking/deposited organics are warranted for a better understanding of the factors controlling the isotopic composition of the sedimentary organic carbon.

\section{Acknowledgments}

This study was supported by the Grant NSC 942611-M-008-002 from the National Science Council of the Republic of China. We thank the captains and crew of the $\mathrm{R} / \mathrm{V}$ Ocean Researcher $\mathrm{I}$ and R/V FR-1 for sampling assistance. We thank the Sediment Trap Laboratory (NCOR) for providing 
trap samples obtained under the Grant NSC 902119-M-110-003. This is NCU-IHS Contribution $\# 53$.

\section{References}

Benner, R., Fogel, M.L., Hodson, R.E., Sprague, E.K., 1987. Depletion of $\mathrm{C}-13$ in lignin and its implications for stable carbon isotope studies. Nature 329, 708-710.

Chao, S.Y., Shaw, P.T., Wu, S.Y., 1996. Deep-water ventilation in the South China Sea. Deep-Sea Research I 43, 445-466.

Chen, M.T., Beaufort, L., Shipboard Scientific Party of the IMAGES III/M 106-IPHIS Cruise (Leg_II), 1998. Exploring Quaternary variability of the East Asia monsoon, Kuroshio Current, and Western Pacific warm pool systems: highresolution investigations of paleoceanography from the IMAGES III (MD106)-IPHIS Cruise. Terrestrial Atmospheric Oceanic Sciences 9, 129-142.

Chen, Y.F.L., 2005. Spatial and seasonal variations of nitratebased new production and primary production in the South China Sea. Deep-Sea Research I 52 (2), 319-340.

Chen, Y.L.L., Chen, H.Y., Karl, D.M., Takahashi, M., 2004. Nitrogen modulates phytoplankton growth in spring in the South China Sea. Continental Shelf Research 24 (4-5), $527-541$

Chou, W.C., 2004. Seasonal variability of $\mathrm{CO}_{2}$ specis and $\mathrm{d}^{13} \mathrm{C}_{\mathrm{TCO} 2}$ in the mixed-layer and their vertical distributions at the SEATS site. Ph.D. Dissertation, National Sun Yat-sen University, Kaohsiung, Taiwan, $211 \mathrm{pp}$.

Chou, W.C., Sheu, D.D., Lee, B.S., Tseng, C.M., Chen, C.T.A., Wang, S.L., Wong, G.T.F., 2007. Depth distributions of alkalinity, $\mathrm{TCO}_{2}$ and $\delta^{13} \mathrm{C}_{\mathrm{TCO} 2}$ at SEATS time-series site, northern South China Sea: controlling processes and anthropogenic $\mathrm{CO}_{2}$ influence. Deep-Sea Research II, this issue [doi:10.1016/j.dsr2.2007.05.002].

DOE, 1994. Handbook of methods for the analysis of the various parameters of the carbon dioxide system in seawater. US Department of Energy $\mathrm{CO}_{2}$ Science Team Report, vol. 2, US Department of Energy.

Ducklow, H.W., 2003. Biogeochemical provinces: towards a JGOFS synthesis (Chapter 1). In: Fasham, M.J.R. (Ed.), Ocean Biogeochemistry: A New Paradigm. Global Change The IGBP Series. Springer, New York, pp. 3-18.

Folland, C.K., et al., 2001. Observed climate variability and change. In: Houghton, J.T., et al. (Eds.), Climate Change 2001: The Scientific Basis. Contribution of Working Group I to the Third Assessment Report of the Intergovernmental Panel on Climate Change. Cambridge University Press, Cambridge, UK, p. 881pp.

Hayes, J.M., 1993. Factors controlling C-13 contents of sedimentary organic- compounds-principles and evidence. Marine Geology 113, 111-125.

Higginson, M.J., Maxwell, J.R., Altabet, M.A., 2003. Nitrogen isotope and chlorin paleoproductivity records from the Northern South China Sea: remote vs. local forcing of millennial- and orbital-scale variability. Marine Geology 201 (1-3), 223-250.

Hoefs, J., 1997. Stable Isotope Geochemistry. Springer, Berlin, $201 \mathrm{pp}$.
Hofmann, M., Wolf-Gladrow, D.A., Takahashi, T., Sutherland, S.C., Six, K.D., Maierreimer, E., 2000. Stable carbon-isotope distribution of particulate organic-matter in the ocean-A model study. Marine Chemistry 72, 131-150.

Jeffrey, A.W.A., Brooks, J.M., Pflaum, R.C., Sackett, W.M., 1983. Vertical trends in particulate organic-carbon C-13-C-12 ratios in the upper water column. Deep-Sea Research 30, 971-983.

Karl, D.M., et al., 2003. Temporal studies of biogeochemical processes in the world's oceans during the JGOFS era. In: Fasham, M.J.R. (Ed.), Ocean Biogeochemistry: The Role of the Ocean Carbon Cycle in Global Change. IGBP Book Series. Springer, Berlin, pp. 239-267.

Kienast, M., 2000. Unchanged nitrogen isotopic composition of organic-matter in the South-China-Sea during the last climatic cycle-global implications. Paleoceanography 15 , 244-253.

Kienast, M., Calvert, S.E., Pelejero, C., Grimalt, J.O., 2001. A critical review of marine sedimentary delta $\mathrm{C}-13_{(\text {org })}-\mathrm{pCO}_{(2)}$ estimates: new palaeorecords from the South China Sea and a revisit of other low-latitude $\mathrm{d}^{13} \mathrm{C}_{(\text {org) }}-\mathrm{pCO}_{(2)}$ records. Global Biogeochemical Cycles 15 (1), 113-127.

Lehmann, M.F., Bernasconi, S.M., Barbieri, A., McKenzie, J.A., 2002. Preservation of organic matter and alteration of its carbon and nitrogen isotope composition during simulated and in situ early sedimentary diagenesis. Geochimica et Cosmochimica Acta 66 (20), 3573-3584.

Lewis, E., Wallace, D., 1998. Program Developed for $\mathrm{CO}_{2}$ System Calculation. Carbon Dioxide Information Analysis Center, Oak Ridge National Laboratory, Oak Ridge, Tennessee, USA, 31pp.

Lin, H.L., Wang, L.W., Wang, C.H., Gong, G.C., 1999. Verticaldistribution of $\mathrm{d}^{13} \mathrm{C}$ of dissolved inorganic carbon in the northeastern South China Sea. Deep-Sea Research I 46 (5), $757-775$.

Liu, K.K., Chao, S.Y., Shaw, P.T., Gong, G.C., Chen, C.C., Tang, T.Y., 2002. Monsoon-forced chlorophyll distribution and primary production in the South China Sea: observations and a numerical study. Deep-Sea Research I 49 (8), $1387-1412$.

Longhurst, A., Sathyendranath, S., Platt, T., Caverhill, C., 1995. An estimate of global primary production in the ocean from satellite radiometer data. Journal of Plankton Research 17 (6), 1245-1271.

McCave, I.N., et al., 2001. Distribution, composition and flux of particulate material over the European margin at $47^{\circ}-50^{\circ} \mathrm{N}$. Deep-Sea Research II 48, 3107-3139.

Middelburg, J.J., Nieuwenhuize, J., 1998. Carbon and nitrogen stable isotopes in suspended matter and sediments from the Schelde Estuary. Marine Chemistry 60, 217-225.

NGDC, 2001. ETOPO2 Global 2-Minute Gridded Elevation Data Volume E1. National Geophysical Data Center, National Oceanographic and Atmospheric Agency, USA.

Petit, J.R., et al., 1999. Climate and atmospheric history of the past 420,000 years from the Vostok ice core, Antarctica. Nature 399, 429-436.

Prell, W.L., Wang, P., Blum, P., 1999. Ocean Drilling Program Leg 184 Preliminary Report: South China Sea. Texas A\&M University, College Station, TX.

Quay, P.D., Sonnerup, R., Westby, T., Stutsman, J., McNichol, A., 2003. Changes of the ${ }^{13} \mathrm{C} /{ }^{12} \mathrm{C}$ of dissolved inorganic 
carbon in the ocean as a tracer of anthropogenic $\mathrm{CO}_{2}$ uptake. Global Biogeochemical Cycles 17 (10), 1029.

Rau, G.H., Kaplan, I.R., Sweeney, R.E., 1982. Plankton ${ }^{13} \mathrm{C}-{ }^{12} \mathrm{C}$ ratio changes with latitude-differences between northern and southern oceans. Deep-Sea Research 29, 1035-1039.

Rau, G.H., Riebesell, U., Wolf-Gladrow, D., 1996. A model of photosynthetic ${ }^{13} \mathrm{C}$ fractionation by marine-phytoplankton based on diffusive molecular $\mathrm{CO}_{2}$ uptake. Marine Ecology Progress Series 133, 275-285.

Rau, G.H., Riebesell, U., Wolf-Gladrow, D., 1997. $\mathrm{CO}_{2 \mathrm{aq}^{-}}$ dependent photosynthetic ${ }^{13} \mathrm{C}$ fractionation in the ocean-A model versus measurements. Global Biogeochemical Cycles 11 (2), 267-278.

Rau, G.H., Chavez, F.P., Friederich, G.E., 2001. Plankton ${ }^{13} \mathrm{C} /{ }^{12} \mathrm{C}$ variations in Monterey Bay, California: evidence of non-diffusive inorganic carbon uptake by phytoplankton in an upwelling environment. Deep-Sea Research I 48 (1), 79-94.

Rau, G.H., Takahashi, T., Des Marais, D.J., 1989. Latitudinal variations in plankton $\delta^{13} \mathrm{C}$ : implications for $\mathrm{CO}_{2}$ and productivity in past oceans. Nature $341,516-518$.

Sarmiento, J.L., Slater, R.D., Fasham, M.J.R., Ducklow, H.W., Toggweiler, J.R., Evans, G.T., 1993. A seasonal three-dimensional ecosystem model of nitrogen cycling in the North Atlantic euphotic zone. Global Biogeochemical Cycles 7, 417-450.

Shaw, P.T., Chao, S.Y., 1994. Surface circulation in the South China Sea. Deep-Sea Research I 41, 1663-1683.

Sverdrup, H.U., Johnson, M.W., Fleming, R.H., 1942. The Oceans. Prentice Hall, New York, 1087pp.
Tseng, C.M., Wong, G.T.F., Lin II, Wu, C.R., Liu, K.K., 2005. A unique seasonal pattern in phytoplankton biomass in lowlatitude waters in the South China Sea. Geophysical Research Letters 32 (8), L08608.

Wang, P.X., Tian, J., Cheng, X.R., Liu, C.L., Xu, J., 2004. Major Pleistocene stages in a carbon perspective: the South China Sea record and its global comparison. Paleoceanography 19 (4), PA4005.

Westerhausen, L., Poynter, J., Eglinton, G., Erlenkeuser, H., Sarnthein, M., 1993. Marine and terrigenous origin of organic-matter in modern sediments of the Equatorial East Atlantic-The $\delta^{13} \mathrm{C}$ and molecular record. Deep-Sea Research I 40 (5), 1087-1121.

Woodworth, M., Goni, M., Tappa, E., Tedesco, K., Thunell, R., Astor, Y., Varela, R., Diaz-Ramos, J.R., Muller-Karger, F., 2004. Oceanographic controls on the carbon isotopic compositions of sinking particles from the Cariaco Basin. Deep-Sea Research I 51 (12), 1955-1974.

Wu, C.-R., Chiang, T.-L., 2007. Mesoscale eddies in the northern South China Sea. Deep-Sea Research II, this issue [doi:10.1016/j.dsr2.2007.05.008].

Wu, C.R., Shaw, P.T., Chao, S.Y., 1999. Assimilating altimetric data into a South China Sea model. Journal of Geophysical Research 104, 29987-30005.

Zhang, J., Quay, P.D., Wilbur, D.O., 1995. Carbonisotope fractionation during gas-water exchange and dissolution of $\mathrm{CO}_{2}$. Geochimica Et Cosmochimica Acta 59, 107-114. 